\title{
The Petrographic Analysis of Sherds from the Craig Mound at the Spiro site (34Lf40), the Moore \#3/Ainsworth site (34Lf31), and the Geren site (34Lf36), LeFlore County, Oklahoma
}

Lori B. Love

Unknown

Steve A. Tomka

Raba Kistner

Timothy K. Perttula

Heritage Research Center, Stephen F. Austin State University

Follow this and additional works at: https://scholarworks.sfasu.edu/ita

Part of the American Material Culture Commons, Archaeological Anthropology Commons, Environmental Studies Commons, Other American Studies Commons, Other Arts and Humanities Commons, Other History of Art, Architecture, and Archaeology Commons, and the United States History Commons

Tell us how this article helped you.

This Article is brought to you for free and open access by the Center for Regional Heritage Research at SFA ScholarWorks. It has been accepted for inclusion in Index of Texas Archaeology: Open Access Gray Literature from the Lone Star State by an authorized editor of SFA ScholarWorks. For more information, please contact cdsscholarworks@sfasu.edu. 


\section{The Petrographic Analysis of Sherds from the Craig Mound at the Spiro site}

(34Lf40), the Moore \#3/Ainsworth site (34Lf31), and the Geren site (34Lf36), LeFlore County, Oklahoma

Creative Commons License

\section{(c) (1) (9)}

This work is licensed under a Creative Commons Attribution-NonCommercial 4.0 International License 


\section{The Petrographic Analysis of Sherds from the Craig Mound AT THE SPIRO SITE (34LF40), THE MOORE \#3/AINSWORTH SITE (34LF31), AND THE GEREN SITE (34LF36), LEFLORE COUNTY, OKLAHOMA}

\section{Lori Barkwill Love, Steve A. Tomka, and Timothy K. Perttula}

\section{Introduction}

James A. Brown (1971, 1996:329) commissioned James W. Porter (1971:244-246) to carry out a preliminary assessment of the paste of sherds from the Spiro site (34Lf40), as well as sherds from the nearby Geren (34Lf36) and Moore (34Lf31) sites. According to Brown (1996:329), Porter's goal was to "make assessments of the clay mineralogy and petrography of thin sections," specifically with an "interest in discriminating between (1) grog and grit temper and (2) shell and grog temper with shell inclusions." Twentynine thin sections were prepared, 27 from sherds from the Craig Mound, and one sherd each from the Moore/ Ainsworth and Geren sites, both not far from Spiro (Brown 1996:Table 2-41; Peterson et al. 1993:Figure 4; Rohrbaugh 1985).

Shortly after Ferring and Perttula (1987) completed petrographic studies of red-slipped pottery from sites in Oklahoma and Texas, Brown offered to send the thin-sections from his Spiro area studies to Ferring for more detailed petrographic studies. This he did sometime in 1987, but the 29 thin-sections were never fully studied, and they languished for years at the University of North Texas. In 2012, Ferring relocated the thin-sections and corresponding sherds and sent them to Perttula to complete the petrographic analysis of the Spiro area sherd series. The results of the petrographic analysis of a total of 23 of the 29 thin-sections are discussed in this article; there are provenience issues with the other six thin-sections (see below).

\section{Context of the Sherds}

The sherds for petrographic analysis are from a variety of burial features in the Craig Mound at the Spiro site, as well as from unknown contexts in the excavations; House 2 at the Geren site (Rohrbaugh 1985); and from a test pit at the Moore site (Table 1). The sherds with known provenience from the Craig Mound date as early as A.D. 1000-1250 (Spiro I/II), in the Evans and Harlan phases, to A.D. 1250-1350 (Spiro III, Norman phase), and to the Spiro phase (Spiro IV and IVB, ca. A.D. 1350-1450) (Brown 1996:Figure 1-51). The Geren site sherd also dates to the Spiro phase. The Moore site dates to both Spiro phase and Fort Coffee phase (ca. A.D. 1450-1660, Rogers 2006) times. 
Table 1. Provenience of the sherds from the Craig Mound at the Spiro site, the Geren site, and the Moore site.

\begin{tabular}{|c|c|c|c|}
\hline $\begin{array}{l}\text { Thin-Section } \\
\text { No. }\end{array}$ & $\begin{array}{l}\text { Catalog No./ } \\
\text { SNOMNH* }\end{array}$ & $\begin{array}{l}\text { Known provenience } \\
\text { and Feature }\end{array}$ & Likely age of the sherd \\
\hline \multicolumn{4}{|c|}{ Craig Mound, Spiro site (34Lf40) } \\
\hline 1 & 860 & Unknown & - \\
\hline 2 & 135 & Unknown & - \\
\hline 3 & 36 & Burial \#034 & $\begin{array}{l}\text { Sub-mound feature, Spiro I/II } \\
\text { (Brown 1966:73, 1996:75,77) }\end{array}$ \\
\hline 5 & 856 & Unknown & - \\
\hline 10 & 130 & Burial \#140 & $\begin{array}{l}\text { Spiro IV (Brown 1966:202- } \\
\text { 203, 1996:Figure 1-47) }\end{array}$ \\
\hline 11 & 856 & Unknown & - \\
\hline 12 & 116 & back dirt in mound & - \\
\hline 13 & 856 & Unknown & - \\
\hline 14 & 251 & Burial \#099 & $\begin{array}{l}\text { Spiro III (Brown 1966:156- } \\
\text { 159; 1996:Figure 1-47) }\end{array}$ \\
\hline 15 & 856 & Unknown & - \\
\hline 16 & 125 & back dirt in mound & - \\
\hline 18 & 166 & Burial \#187 & $\begin{array}{l}\text { Spiro III, crematory basin } \\
\text { (Brown 1966:255-256, } \\
\text { 1996:75, 77, 751) }\end{array}$ \\
\hline 19 & 116 & back dirt in mound & - \\
\hline 20 & 856 & Unknown & - \\
\hline 21 & 43 & Burial \#145 & $\begin{array}{l}\text { Spiro IVB (Brown 1966:205- } \\
\text { 207, 1996:Table 2-154) }\end{array}$ \\
\hline 22 & 856 & Unknown & - \\
\hline 23 & 109 & Unknown & - \\
\hline 24 & 150 & Burial \#094 & $\begin{array}{l}\text { Spiro IV (Brown 1966:151- } \\
\text { 153, 1996:749) }\end{array}$ \\
\hline 25 & 790 & Unknown & - \\
\hline 26 & 86 & Unknown & - \\
\hline 27 & 66 & Unknown & - \\
\hline \multicolumn{4}{|c|}{ Geren (34Lf36) } \\
\hline 28 & 102 & House \#2 & $\begin{array}{l}\text { Spiro phase (Rohrbaugh1985; } \\
\text { Peterson et al.1993:Table 1) }\end{array}$ \\
\hline \multicolumn{4}{|c|}{ Moore \#3/Ainsworth (34Lf31) } \\
\hline 29 & 118 & Test Pit \#3 & $\begin{array}{l}\text { Spiro and Fort Coffee phases } \\
\text { (Peterson et al. 1993:Table 1; } \\
\text { Rohrbaugh 2012) }\end{array}$ \\
\hline
\end{tabular}

*catalog number preceded by the trinomial, i.e., 34Lf40/0036

The catalog numbers listed on Table 1 do not correspond in every detail with the information provided in Brown (1996:Table 2-41). For this study, we relied on our decipherment of the catalog numbers written on the sherds; unfortunately, several sherds were so fragmentary that catalog numbers could not be deciphered, and in that case, its corresponding thin section could not be determined. This is why thin sections 4, 6-9, and 17 were not examined in this study. 
The petrographic thin sections are from sherds of several different defined ceramic types, as classified by Brown (1996). These include Agee Incised ( $n=1)$, Bell Plain ( $n=1)$, LeFlore Plain ( $n=2)$, Nash Neck Banded ( $n=1)$, Poteau Plain ( $n=5)$, Redland Engraved ( $n=1)$, Sanders Plain ( $n=9)$, Spiro Engraved ( $n=1)$, Williams Plain ( $\mathrm{n}=1)$, and Woodward Plain $(\mathrm{n}=1)$ (Table 2). The grog, grit, and bone-tempered ceramics ( $n=16,70 \%$ of the thin-sections) include Agee Incised, LeFlore Plain, Nash Neck Banded, Redland Engraved, Sanders Plain, Spiro Engraved, and Williams Plain (Brown 1996:343-379, 401-403), while the shell-tempered ceramic types identified in this assemblage ( $\mathrm{n}=7,30 \%$ of the thin-sections) are Bell Plain, Poteau Plain, and Woodward Plain (Brown 1996:389-393, 405-406). The Bell Plain type is considered to be a Mississippi Valley type (Brown 1996:392), while the others are Arkansas River basin Caddo area ceramic types or in the case of Nash Neck Banded, the Red River basin in southeastern Oklahoma and northeastern Texas (Suhm and Jelks 1962:111).

Table 2. Pottery type identifications for the petrographic thin sections from the Craig Mound, the Geren site, and the Moore site (from Brown 1996:Table 2-41).

\begin{tabular}{cl}
\hline Petrographic thin-section no. & Pottery type \\
\hline Spiro site, Craig Mound & \\
1 & Sanders Plain \\
2 & Sanders Plain \\
3 & Williams Plain \\
5 & Spiro Engraved \\
10 & Poteau Plain \\
11 & Sanders Plain \\
12 & Sanders Plain \\
13 & Redland Engraved \\
14 & Bell Plain \\
15 & Agee Incised \\
16 & Sanders Plain \\
18 & Poteau Plain \\
19 & Poteau Plain \\
20 & Poteau Plain \\
21 & Sanders Plain \\
22 & Sanders Plain \\
23 & LeFlore Plain \\
24 & LeFlore Plain \\
25 & Sanders Plain \\
26 & Poteau Plain \\
27 & Sanders Plain \\
& \\
Geren site & \\
28 & Nash Neck Banded \\
Moore site & \\
29 & Woodward Plain \\
\hline
\end{tabular}




\section{Results of the Petrographic Analysis}

\section{Methods}

The thin sections were examined with a Leica Petrographic microscope with an attached mechanical stage. A two-step process was used to examine the thin sections. The first step involved recording their general characteristics and taking photomicrographs of the thin sections. The general characteristics recorded were paste matrix descriptions, paste color, b-fabric (Stoops 2003:95), and description of edges. B-fabric refers to the orientation and distribution of inference colors in the clay matrix (Stoops 2003:95). Examining the b-fabric can provide some insight into firing temperatures. According to Quinn (2013:191) it is generally assumed that an active $\mathrm{b}$-fabric is related to ceramics that have been fired at temperatures less than $850^{\circ} \mathrm{C}$, while an undifferentiated $b$-fabric is related to ceramics that have been fired at temperatures greater than $850^{\circ} \mathrm{C}$. For the samples in this study, all but sample 28 from the Geren site had a slightly active b-fabric. Sample 28 had an undifferentiated b-fabric, suggesting it may have been fired at a slightly higher temperature.

Seven of the thin sections from the Spiro site (Nos. 1, 2, 3, 5, 10,11, and 12) were not cut transverse to the plane of the sherd so that the edges of the vessel could not be described. By cutting a sherd transverse to the plane of the sherd, a slip or other surface treatments can be distinguished or described; however, given that several of the sherds were not cut transverse to the plane of the sherd and others were ground down too thin or had the edge eroded, a discussion of a slip or other surface treatments has not been included in this article. For the photomicrographs, at least two sets (plane light and cross-polar light) were taken of each thin section at 4x and 10x magnification. Digital images were captured using a Leica DFC 295 Digital Camera attached to a Dell computer.

The second step involved point counting using the Glagolev-Chayes method. The Glagolev-Chayes method involves using the mechanical stage, which allows one to move the thin section at a given interval beneath the crosshairs in the ocular, and identifying and recording each point encountered in the crosshairs (Galehouse 1971:389-390). For the point count sampling, the microscope was set at 10x magnification, and the stage was set so that the vertical and horizontal increments were both $0.4 \mathrm{~mm}$. Each point encountered was identified as either paste matrix, void, or non-plastic inclusion. Paste matrix was recorded by tally; however, for all voids and non-plastic inclusions, estimated size and shape were recorded. Non-plastic inclusions and voids were only counted once even if the same void or inclusion was encountered more than once in the crosshairs. Once the point counting was completed, non-plastic inclusions that were noted during the scanning of the slide but not included in the point counting were recorded with a general estimate of their frequency.

Initially the thin sections were point counted until 100 paste points were reached. Stoltman (1989:151-152, 2012:H-1) suggests that a minimum of 100 points (exclusive of voids) are needed to ensure reliable results and that point counting in excess of 200 points yields redundancy. With 100 paste points counted, the minimum number of points recorded was 108, and the maximum number of points recorded was 168. However, in many of these thin sections, several of the inclusions had been "popped out," and the majority of the non-paste points recorded were voids, which do not provide much information regarding the temper in the sherds. Therefore, the point counting was repeated and increased to 200 paste points to ensure that a greater number of non-plastic inclusions were recorded. With the revised point counting, the minimum number of points recorded was 226 and the maximum number of points was 346. In the individual thin section descriptions, the percentage of voids that might represent "popped out" inclusions was recorded. The recording of missing inclusions was based primarily on the shape of the voids. The counts, measurements and 
paste, voids, and non-plastic inclusion type recorded during point counting for each thin section were input into a JMP Pro 10 data table.

The maximum diameter of the inclusion/void was measured with the ocular scale to the nearest whole number. At 10x magnification, each tick mark on the ocular scale represents $0.02 \mathrm{~mm}$. The raw tick mark count was recorded for each inclusion, input into JMP and converted to an actual size. Within each temper category, the distribution of sand size was noted by size category based on the Wentworth Grain Size scale (Table 3).

Table 3. Wentworth Grain Size scale used for distribution of sand size.

\begin{tabular}{|c|c|}
\hline Size Category & Recorded Size \\
\hline Silt & $0.02-0.06 \mathrm{~mm}$ \\
\hline Very Fine Sand & $0.07-0.12 \mathrm{~mm}$ \\
\hline Fine Sand & $0.13-0.25 \mathrm{~mm}$ \\
\hline Medium Sand & $0.26-0.50 \mathrm{~mm}$ \\
\hline Coarse Sand & $0.51-1.0 \mathrm{~mm}$ \\
\hline Very Coarse Sand & $1.01-2.0 \mathrm{~mm}$ \\
\hline
\end{tabular}

\section{Temper Categories}

To assign temper categories to the thin-sections in the study, the recorded paste/inclusions were combined into the following simplified categories:

$\begin{array}{ll}\text { Recorded Paste/Inclusion } & \text { Simplified Inclusion Category } \\ \text { Paste } & \text { Paste } \\ \text { Bone } & \text { Bone } \\ \text { Sherd } & \text { Grog } \\ \text { Shell } & \text { Shell } \\ \text { Quartz } & \text { Sand } \\ \text { Polycrystalline quartz } & \text { Sand } \\ \text { Alkali feldspar } & \text { Sand } \\ \text { Muscovite } & \text { Mica } \\ \text { Calcium carbonate } & \text { Other } \\ \text { Clay pellet } & \text { Other } \\ \text { Hematite } & \text { Other } \\ \text { Opaque } & \text { Other } \\ \text { Organic } & \text { Other } \\ \text { Voids } & \text { Not included } \\ \text { Biotite } & \text { Mica } \\ \text { Calcite } & \text { Other } \\ \text { Chert } & \text { Sand } \\ \text { Mica Schist } & \text { Mica } \\ \text { Microcline } & \text { Sand } \\ \text { Secondary Calcite } & \text { Not included } \\ \text { Unknown } & \text { Other }\end{array}$


A frequency distribution was created for each sherd based on the simplified inclusion category (voids and secondary calcite excluded) to determine temper categories. The "other" category was not used in temper assignments given that this category made up less than $5 \%$ of the inclusion categories. Eight temper categories were defined for these thin-sections: bone $(n=4,17 \%)$; bone and grog $(n=5,22 \%)$; grog $(n=6$, $26 \%)$; grog and sand $(n=1,4 \%)$; shell $(n=4,17 \%)$; shell and grog $(n=1,4 \%)$; shell, bone and grog $(n=1,4 \%)$; and micaceous sand $(n=1,4 \%)$. Grog was the most common category represented, followed by bone and grog (Figure 1).

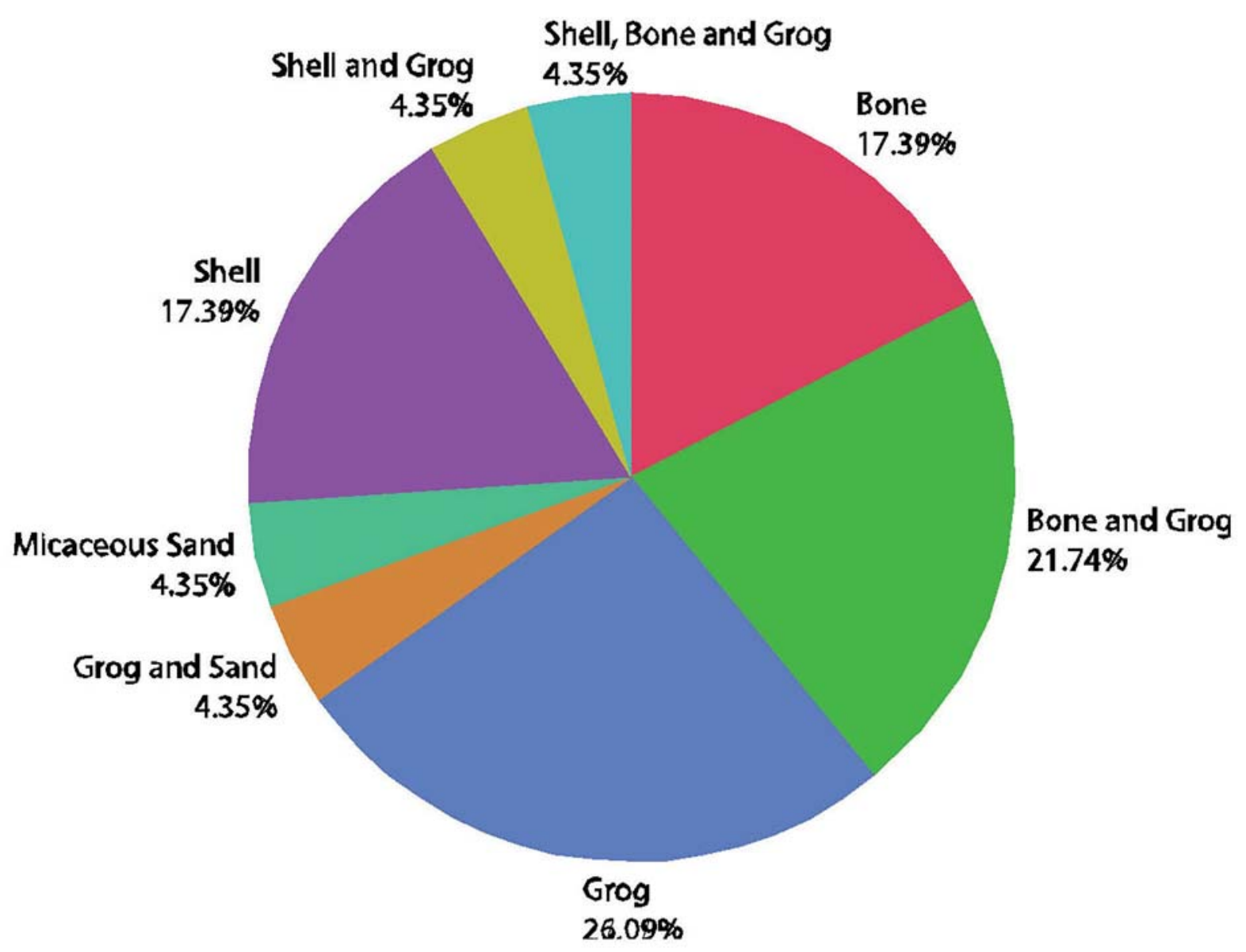

Figure 1. Distribution of temper categories.

\section{Summary of Petrographic Analysis}

Table 4 provides a general summary of the thin sections analyzed from the Spiro, Moore \#3, and Geren sites. The table is divided by temper categories and provides an overview of the individual thin sections. The following is a description of the table columns: 
Sherd ID: the ID number etched on the thin sections

Simplified Inclusion Categories (paste \%, sand \%, bone \%, grog \%, shell \%, and mica \%): lists the percentage of each category found during point counting. Note that the "other" inclusion category was omitted from this table.

Median Sand Size: represents the median size for the sand inclusions in the thin section.

Median Inclusion Size: represents the median size for all inclusions excluding sand and voids.

Platy Bone Inclusions: lists whether or not platy bone inclusions were common in the thin section. $Y=$ platyshaped bone was common, $\mathrm{N}$ = bone was generally not platy-shaped.

Platy Shell Inclusions: lists whether or not platy shell inclusions were common in the thin section. $\mathrm{Y}=$ platyshaped shell was common, $\mathrm{N}$ = shell was generally not platy-shaped.

Common Inclusions (feldspar, mica, and hematite): lists whether or not these inclusions were common in the thin section based on visual inspection and not point counting. $Y=$ inclusion was common, $\mathrm{N}=$ inclusion was not common.

Temper of Grog (sand, bone, shell, or grog):based on visual inspection, lists the temper commonly found in the grog. $\mathrm{Y}=$ temper type was commonly present, $\mathrm{N}=$ temper type was not present, $\mathrm{P}=$ temper type was present and the inclusions were often platy-shaped. In some of the thin sections only voids were represented in the crushed sherds; therefore, it was not possible to distinguish shell from bone, so both were recorded as being present.

\section{Bone Temper}

The bone temper category was defined on the presence of bone without grog or shell present in thin sections No. 13, 14, 19, and 26 from the Spiro site (see Table 4). The percentage of bone in this category ranged from $5.4 \%$ to $16.5 \%$. A box plot of the bone size distribution by sherd No. is shown in Figure 2 . Given the small sample size of the individual inclusions in each sherd, a statistical analysis comparing size differences was not warranted. The percentage of sand in this temper category ranged from $1.3 \%$ to $10.8 \%$. Figure 3 shows the sand size distribution based on the Wentworth scale categories. Sand size is represented by a histogram rather than a box plot given that distinguishing silty sand from other sand categories is useful in determining whether the sand was a natural inclusion in the clay or intentionally added as temper. Since the majority of the sand in each of the thin sections is silt-sized, it is likely that the sand was a natural constituent in the clay for the samples in this category. However, the higher percentage of sand in thin section No. 19 (see Table 4) suggests this vessel was likely made with a sandier clay.

Of particular interest was the shape of the bone found in these thin sections. With the exception of thin section No. 13, the crushed bone was platy-shaped (Figure 4). This difference in bone shape could represent different ceramic vessel manufacturing processes. 


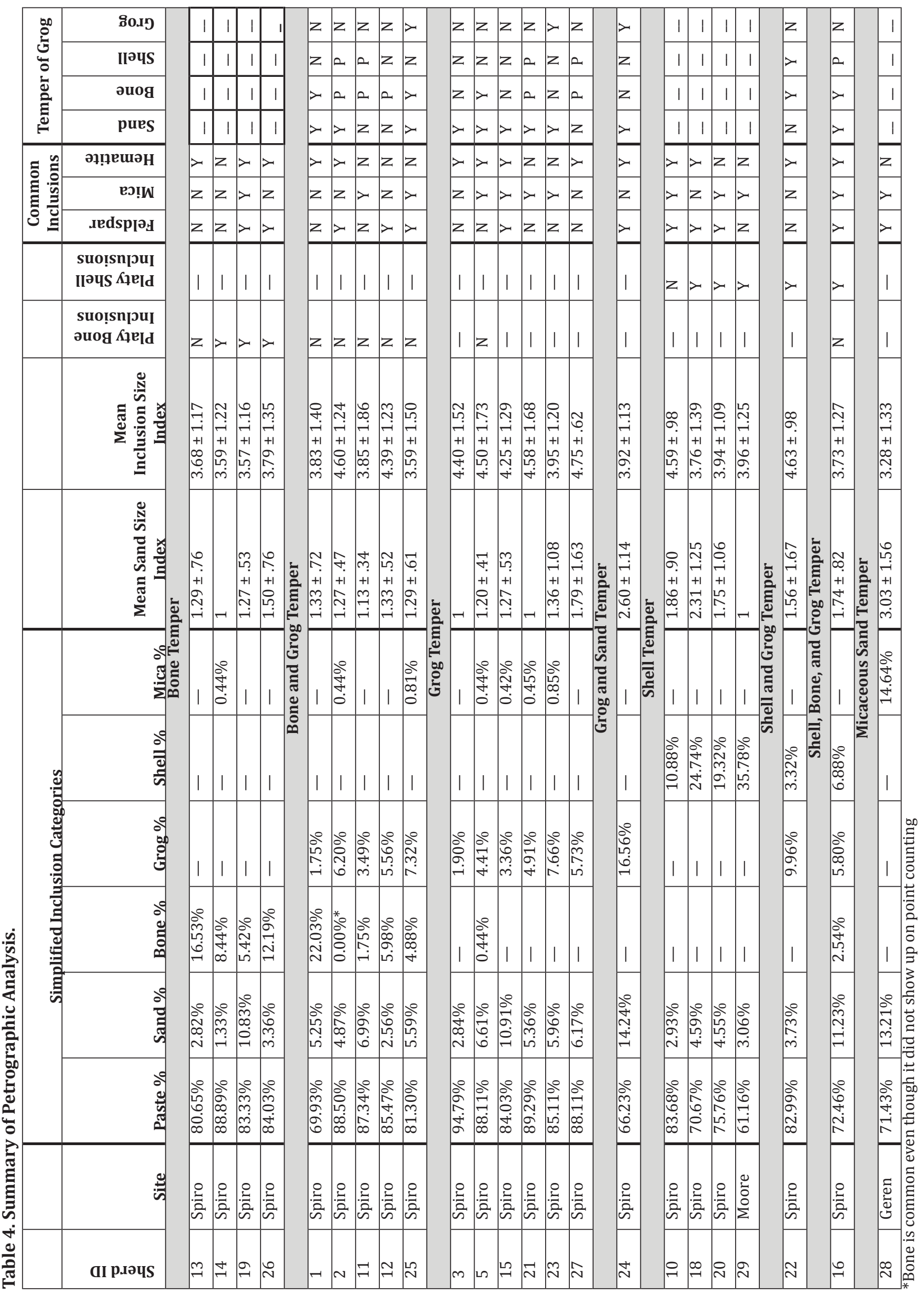




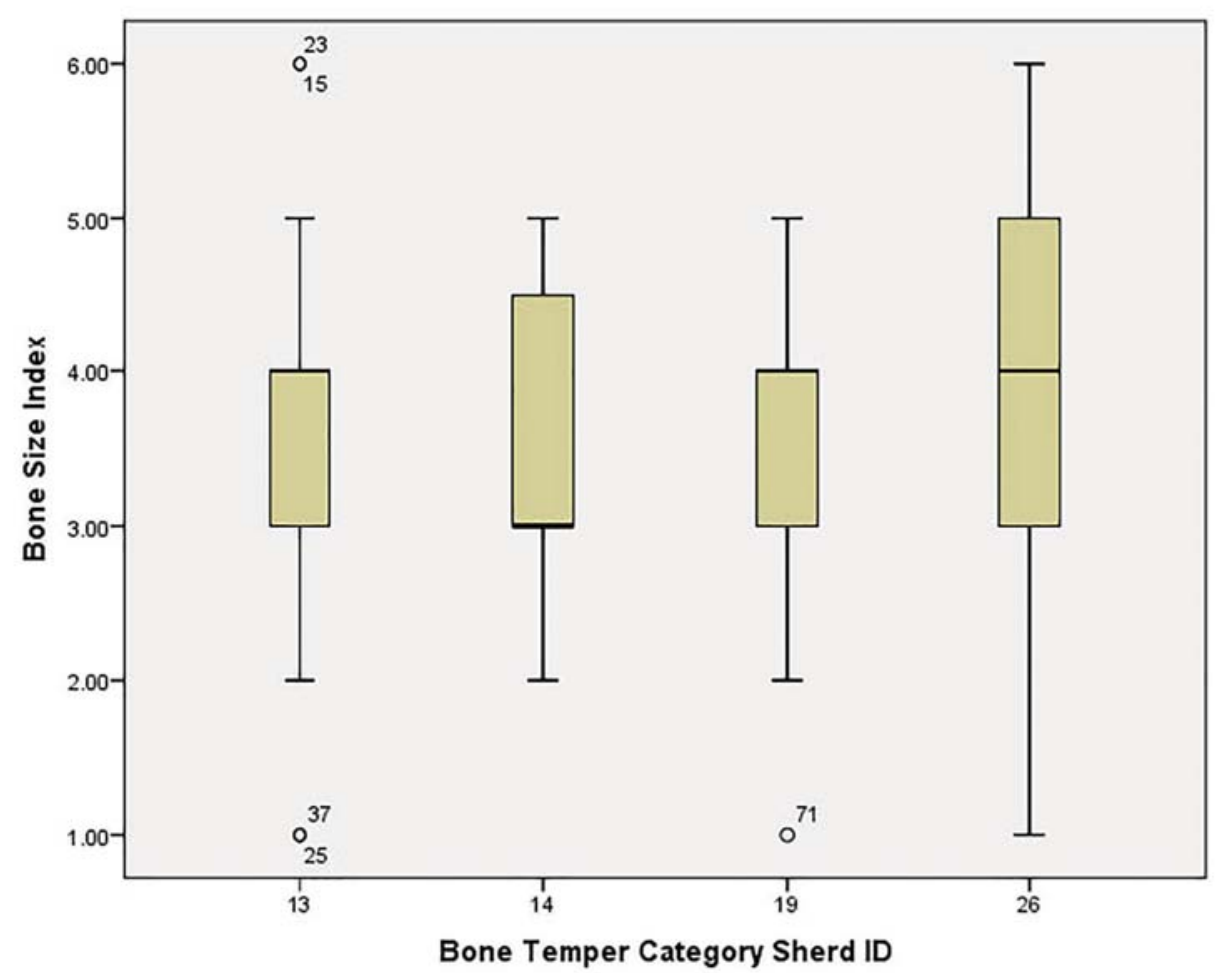

Figure 2. Box plot showing the bone size index for bone-tempered sherds by sherd No.

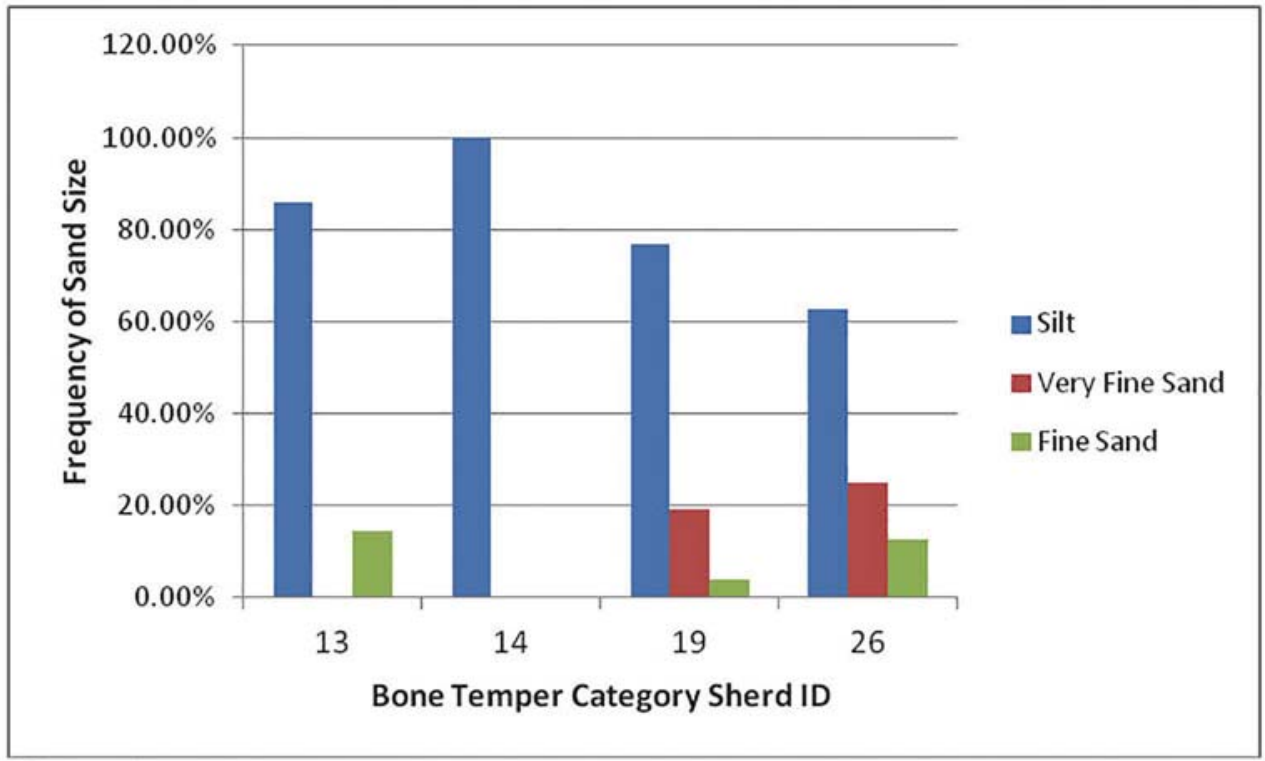

Figure 3. Distribution of sand size categories (based on the Wentworth scale) by sherd No. for bone-tempered sherds. 


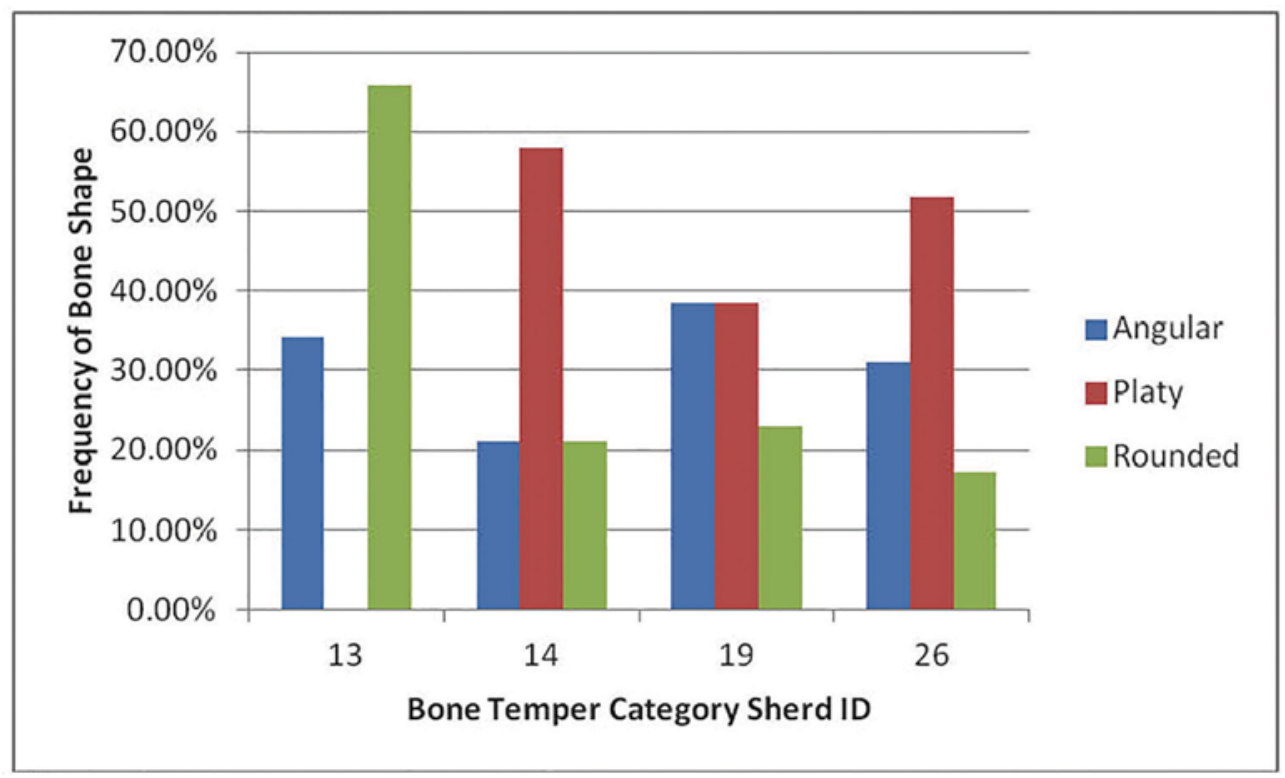

Figure 4. Distribution of crushed bone temper shape by Sherd No. for the bone-tempered sherds.

\section{Sherd No. 13 (Figure 5a)}

Paste Matrix (PPL): Continuous

Paste Color (PPL): 2.5Y 6/6, olive yellow

B-fabric (XPL): Speckled/Slightly Active

Edge Description: One edge has a more active b-fabric. Same inclusions as rest of paste.

Comments: Most bone does not have platy shape. Some of the bone appears to have spots of hematite.

\section{Point Count}

\begin{tabular}{|l|r|r|l|r|r|}
\hline \multicolumn{1}{|c|}{ Paste/Inclusion } & \multicolumn{1}{c|}{ Count } & \multicolumn{1}{c|}{ Percent } & $\begin{array}{c}\text { Simplified Inclusion } \\
\text { Category }\end{array}$ & Count & Percent \\
\hline Paste & 200 & $75.5 \%$ & Paste & 200 & $80.7 \%$ \\
\hline Bone & 41 & $15.5 \%$ & Sand & 7 & $2.8 \%$ \\
\hline Quartz & 7 & $2.6 \%$ & Bone & 41 & $16.5 \%$ \\
\hline Voids & 17 & $6.4 \%$ & Total & $\mathbf{2 4 8}$ & \\
\hline Total & $\mathbf{2 6 5}$ & & & & \\
\hline
\end{tabular}

Also present: polycrystalline quartz (common), hematite (common), charcoal (rare), muscovite (rare), alkali feldspar (rare)

Percentage of voids that might be missing inclusions: $82.4 \%$

Inclusion Size (mm)

\begin{tabular}{|l|c|c|c|c|}
\hline & Range & Mean & Median & $\begin{array}{c}\text { Interquartile } \\
\text { Range }\end{array}$ \\
\hline Sand & $.02-.24$ & .06 & .02 & .02 \\
\hline Bone & $.06-1.5$ & .39 & .34 & .25 \\
\hline All Inclusions* & $.02-1.5$ & .34 & .26 & .36 \\
\hline
\end{tabular}

*Note: All inclusions includes all non-plastic inclusions but not voids 

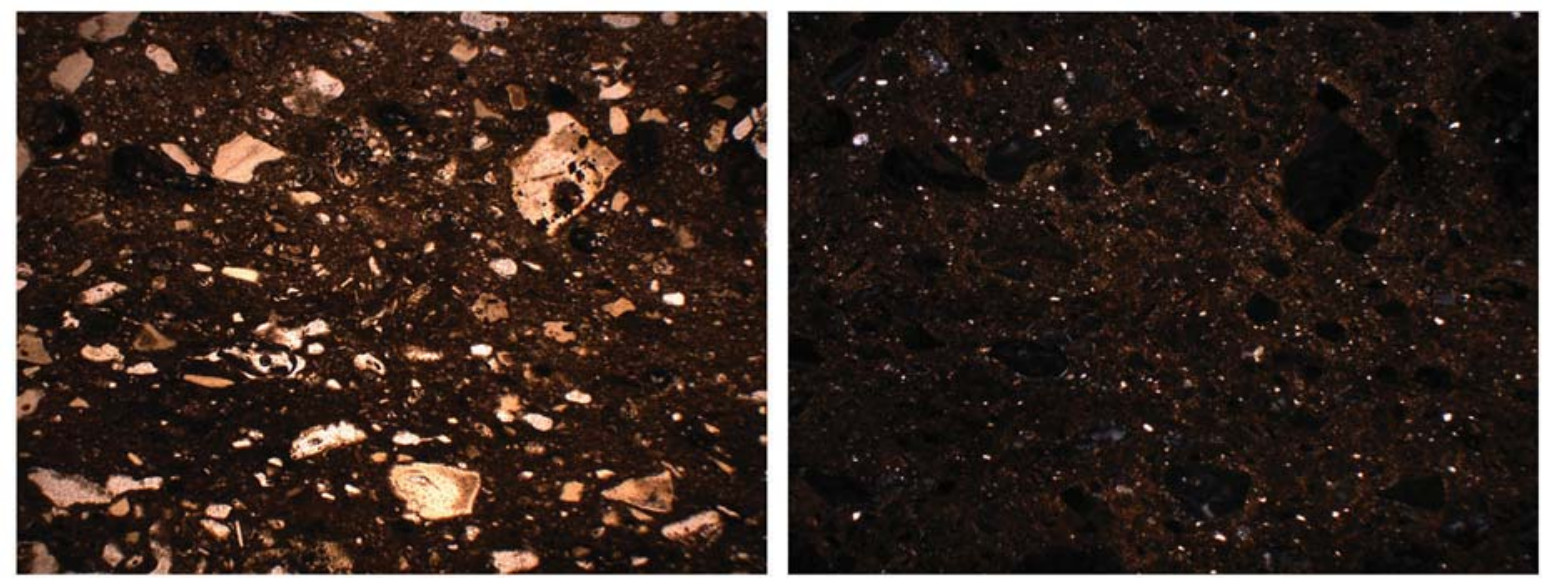

Figure 5a.
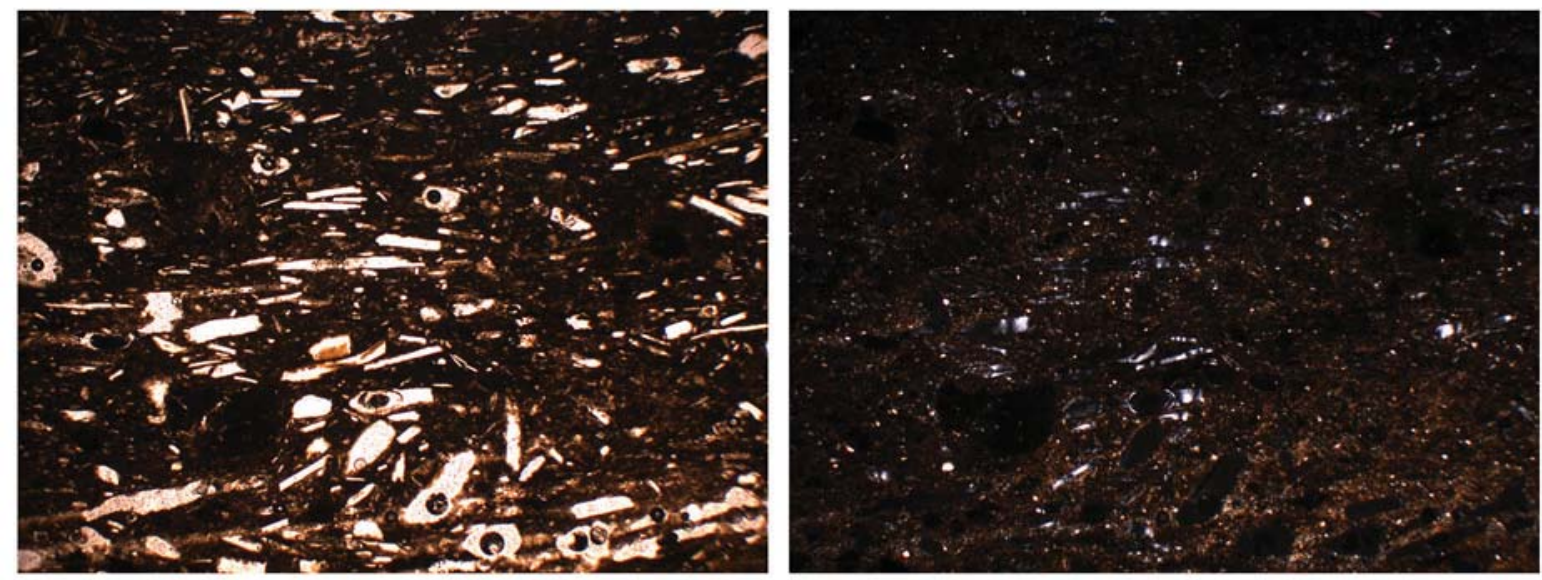

Figure 5b.
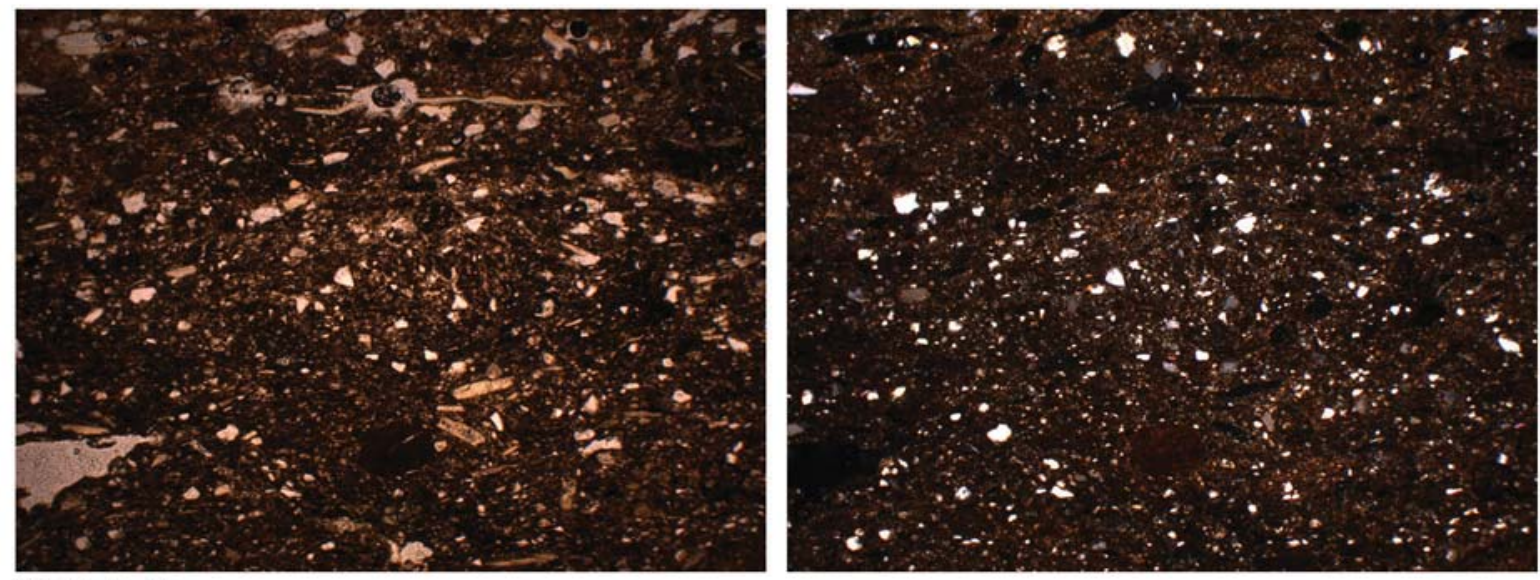

Figure 5c. 

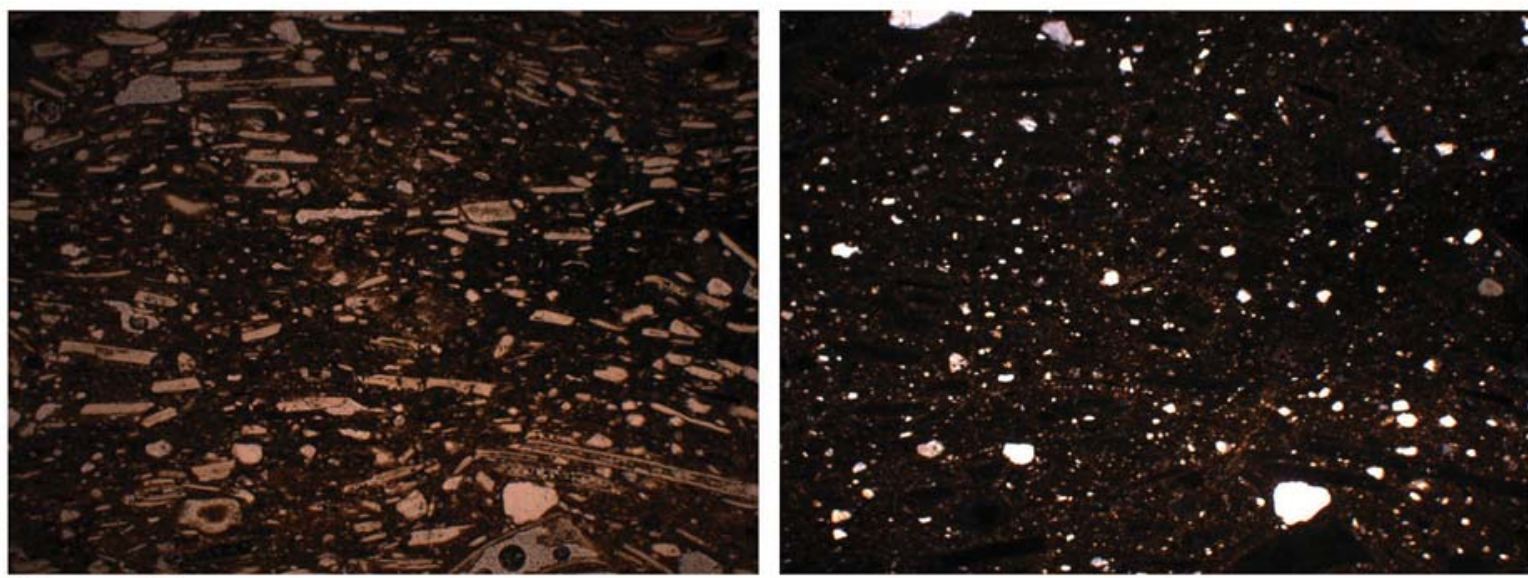

\section{Figure 5d.}

Figure 5. Photographs of bone-tempered thin sections: a, No. 13; b, No. 14; c, No. 19; d, No. 26. All photographs are at $4 \mathrm{x}$ magnification. The plane light image is on the right and the cross-polar light image is on the left.

\section{Sherd No. 14 (Figure 5b)}

Paste Matrix (PPL): Mottled

Paste Color (PPL): 2.5Y 4/3, olive brown with spots of 2.5Y 6/4, light yellowish-brown

$B$-fabric (XPL): Speckled/Slightly Active; Lighter paste is more active

Edge Description: Spots along one edge more active: same inclusions as rest of the paste

Comments: Bone mostly has platy shape. Inclusion generally oriented parallel to the rim.

\section{Point Count}

\begin{tabular}{|l|r|r|l|r|r|}
\hline \multicolumn{1}{|c|}{ Paste/Inclusion } & Count & Percent & $\begin{array}{c}\text { Simplified Inclusion } \\
\text { Category }\end{array}$ & Count & Percent \\
\hline Paste & 200 & $78.4 \%$ & Paste & 200 & $88.9 \%$ \\
\hline Bone & 19 & $7.5 \%$ & Sand & 3 & $1.3 \%$ \\
\hline Quartz & 3 & $1.2 \%$ & Bone & 19 & $8.4 \%$ \\
\hline Muscovite & 1 & $0.4 \%$ & Mica & 1 & $0.4 \%$ \\
\hline Clay pellet & 2 & $0.8 \%$ & Other & 2 & $0.9 \%$ \\
\hline Voids & 30 & $11.8 \%$ & Total & & \\
\hline Total & $\mathbf{2 5 5}$ & & & & \\
\hline
\end{tabular}

Also present: polycrystalline quartz (rare)

Percentage of voids that might be missing inclusions: $80 \%$

Inclusion Size (mm)

\begin{tabular}{|l|c|c|c|c|}
\hline & Range & Mean & Median & $\begin{array}{c}\text { Interquartile } \\
\text { Range }\end{array}$ \\
\hline Sand & $.02-.06$ & .04 & .04 & .04 \\
\hline Bone & $.08-.94$ & .34 & .22 & .36 \\
\hline All Inclusions & $.02-1.5$ & .34 & .26 & .36 \\
\hline
\end{tabular}




\section{Sherd No. 19 (Figure 5c)}

Paste Matrix (PPL): Continuous

Paste Color (PPL): 10YR 5/6, yellowish brown

$B$-fabric (XPL): Speckled/Slightly Active

Edge Description: Both edges are rubbed a little thin and are lighter in color (2.5Y 7/6 yellow) and more active Comments: Clay pellet may be grog without distinctive temper (sand). Most bone has a platy shape and is oriented parallel to the rim.

\section{Point Count}

\begin{tabular}{|l|r|r|l|r|r|}
\hline \multicolumn{1}{|c|}{ Paste/Inclusion } & Count & Percent & $\begin{array}{l}\text { Simplified Inclusion } \\
\text { Category }\end{array}$ & Count & Percent \\
\hline Paste & 200 & $79.4 \%$ & Paste & 200 & $83.3 \%$ \\
\hline Bone & 13 & $5.2 \%$ & Sand & 26 & $10.8 \%$ \\
\hline Quartz & 22 & $8.7 \%$ & Bone & 13 & $5.4 \%$ \\
\hline $\begin{array}{l}\text { Polycrystalline } \\
\text { quartz }\end{array}$ & 4 & $1.6 \%$ & Other & 1 & $0.4 \%$ \\
\hline Clay pellet & 1 & $0.4 \%$ & Total & $\mathbf{2 4 0}$ & \\
\hline Voids & 12 & $4.8 \%$ & & & \\
\hline Total & $\mathbf{2 5 2}$ & & & & \\
\hline
\end{tabular}

Also present: muscovite (common), hematite (common), alkali feldspar (uncommon), plagioclase

(uncommon), shell (uncommon)

Percentage of voids that might be missing inclusions: $58.3 \%$

\section{Inclusion Size (mm)}

\begin{tabular}{|l|c|c|c|c|}
\hline & Range & Mean & Median & $\begin{array}{c}\text { Interquartile } \\
\text { Range }\end{array}$ \\
\hline Sand & $.04-.16$ & .06 & .06 & .03 \\
\hline Bone & $.06-.70$ & .31 & .26 & .27 \\
\hline All Inclusions & $.04-.70$ & .16 & .06 & .17 \\
\hline
\end{tabular}

\section{Sherd No. 26 (Figure 5d)}

Paste Matrix (PPL): Continuous with core

Paste Color (PPL): 10YR 5/6, yellowish brown - core: 10YR 4/3, brown

$B$-fabric (XPL): Speckled/Slightly Active

Edge Description: Possible slip - one edge has spots (not continuous) of 7.5YR 4/6, strong brown - unlike the rest of the paste these spots do not have any bone present, just sand. The other edge is ground too thin. Comments: A large area in the middle of the thin section is missing; this area was skipped during point counting. Most of the bone/voids are platy-shaped and oriented parallel to the rim. There are spots of hematite on the bone. Hematite is common in the thin section.

\section{Point Count}

\begin{tabular}{|l|r|r|l|r|r|}
\hline \multicolumn{1}{|c|}{ Paste/Inclusion } & Count & Percent & $\begin{array}{c}\text { Simplified } \\
\text { Inclusion Category }\end{array}$ & Count & Percent \\
\hline Paste & 200 & $77.2 \%$ & Paste & 200 & $84.0 \%$ \\
\hline Bone & 29 & $11.2 \%$ & Sand & 8 & $3.4 \%$ \\
\hline Quartz & 8 & $3.1 \%$ & Bone & 29 & $12.2 \%$ \\
\hline Hematite & 1 & $0.4 \%$ & Other & $\mathbf{2 3 8}$ & $0.4 \%$ \\
\hline Voids & 21 & $8.1 \%$ & Total & & \\
\hline Total & $\mathbf{2 5 9}$ & & & &
\end{tabular}

Also present: alkali feldspar (common), polycrystalline quartz (rare), muscovite (rare)

Percentage of voids that might be missing inclusions: $66.7 \%$ 
Inclusion Size (mm)

\begin{tabular}{|l|c|c|c|c|}
\hline & Range & Mean & Median & $\begin{array}{c}\text { Interquartile } \\
\text { Range }\end{array}$ \\
\hline Sand & $.02-.14$ & .07 & .06 & .07 \\
\hline Bone & $.06-2.56$ & .47 & .34 & .49 \\
\hline All Inclusions & $.02-2.56$ & .39 & .27 & .49 \\
\hline
\end{tabular}

\section{Bone and Grog Temper}

The bone and grog temper category was defined on the basis of the presence of bone and grog with little to no shell. The bone and grog temper category represented $21.7 \%$ of the samples (see Table 4 ).

The percentage of bone ranged from $0 \%$ to $22 \%$. Although thin section No. 2 had no bone sampled during point counting, bone was common in the thin section; therefore, it was placed in this temper group. A box plot of the bone size distribution by sherd No. is shown in Figure 6. Unlike the bone temper category, the majority of the crushed bone in the thin sections were not platy-shaped, which may represent differences in manufacturing processes between vessels (Figure 7). Although the majority of the crushed bone in the thin section did not have a platy shape, the bone/shell in the crushed sherds used as temper was often platy shaped in all the thin sections except in thin sections No. 1 and No. 25. In some of the thin sections, the inclusions in the crushed sherds were represented by voids instead of actual inclusions; therefore, it was difficult to distinguish between bone and shell inclusions. The mix of temper preparation techniques within the sherd has some interesting implications for recycling of broken vessels or suggests some flexibility in manufacture techniques.

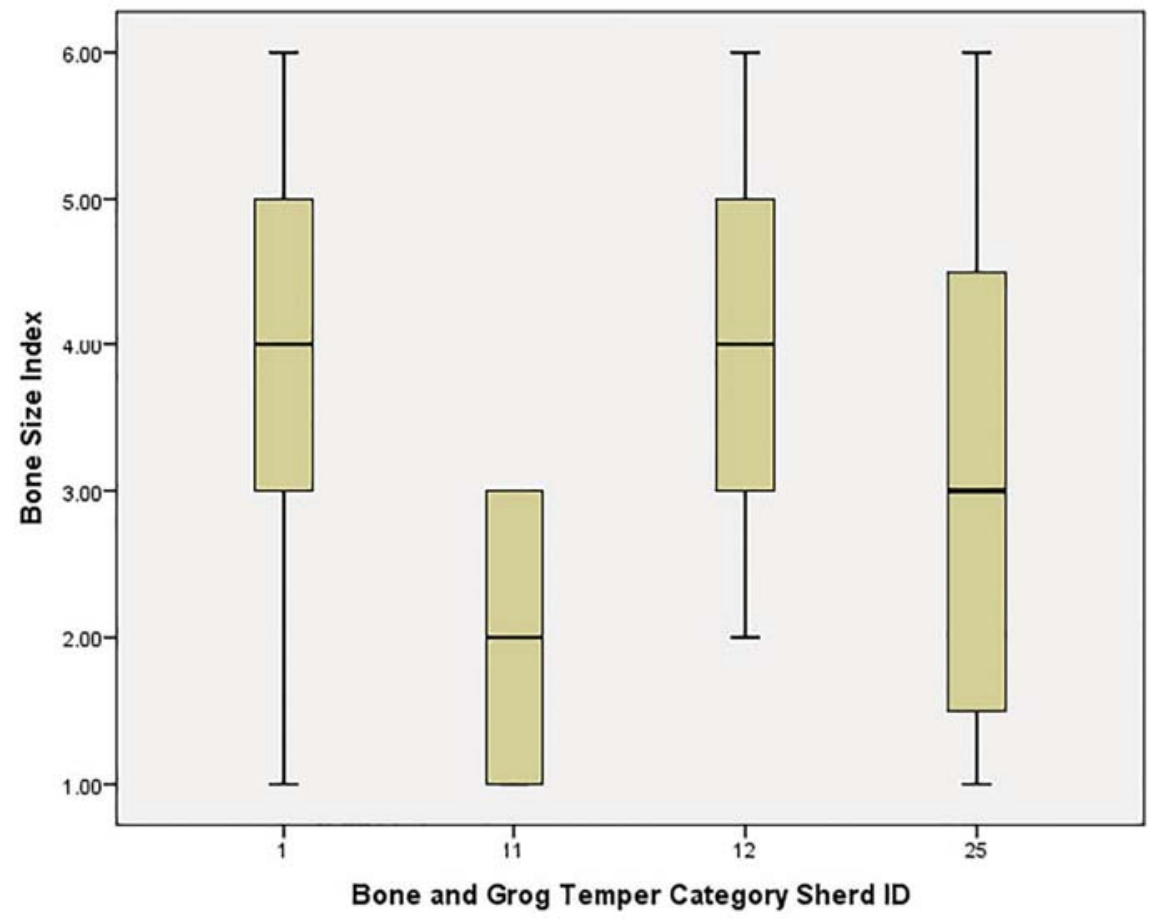

Figure 6. Box plot showing distribution of bone size by sherd No. for bone-grog-tempered sherds. Thin section No. 2 is omitted due to no bone being sampled in the point counting. 


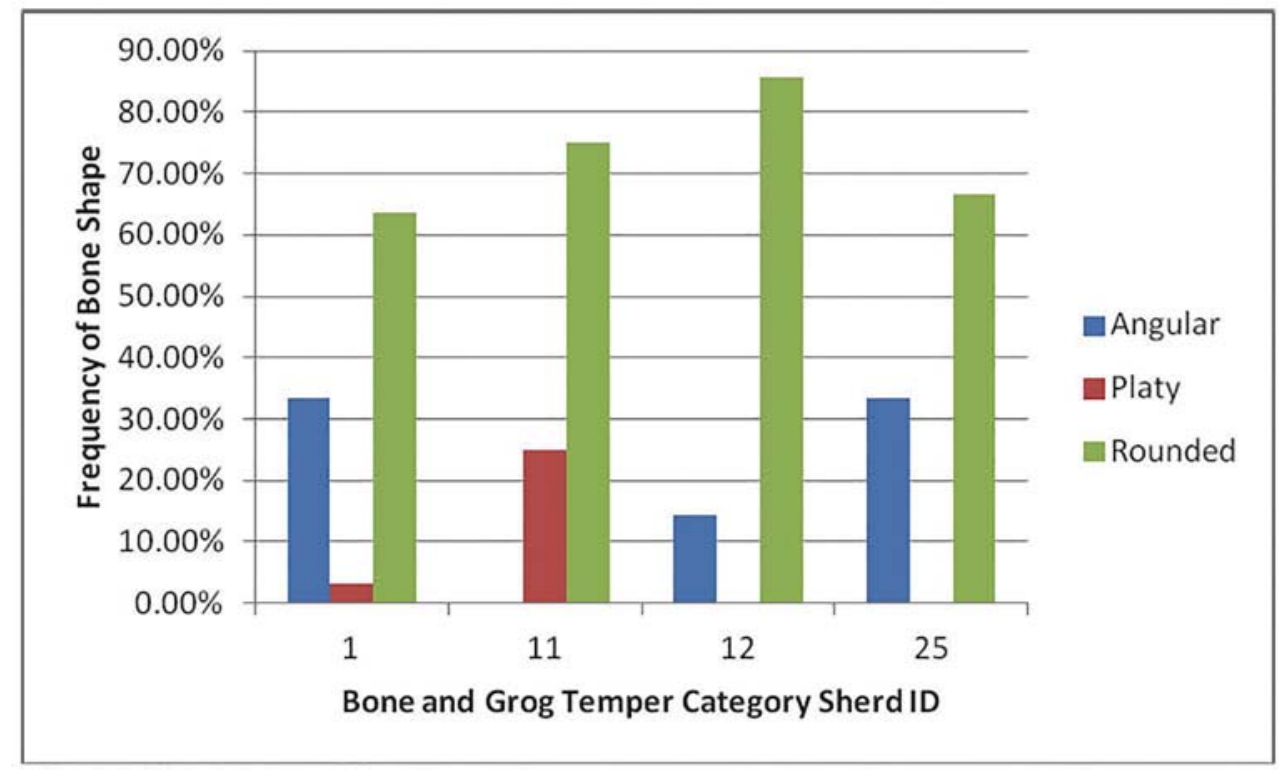

Figure 7. Distribution of the crushed bone shape by Sherd No. Thin section No. 2 is omitted due to no bone being sampled in the point counting.

The percentage of grog in this temper category ranged from $1.8 \%$ to $7.3 \%$. A box plot of the grog size distribution based on the size index by sherd No. is shown in Figure 8. The percentage of sand in this temper category ranged from $2.56 \%$ to $6.99 \%$. Figure 9 shows the sand size distribution based on the Wentworth scale. Given that the majority of the sand in each of the thin sections is silt sized, it is likely that the sand was a natural constituent element in the clay for all the samples in this category.

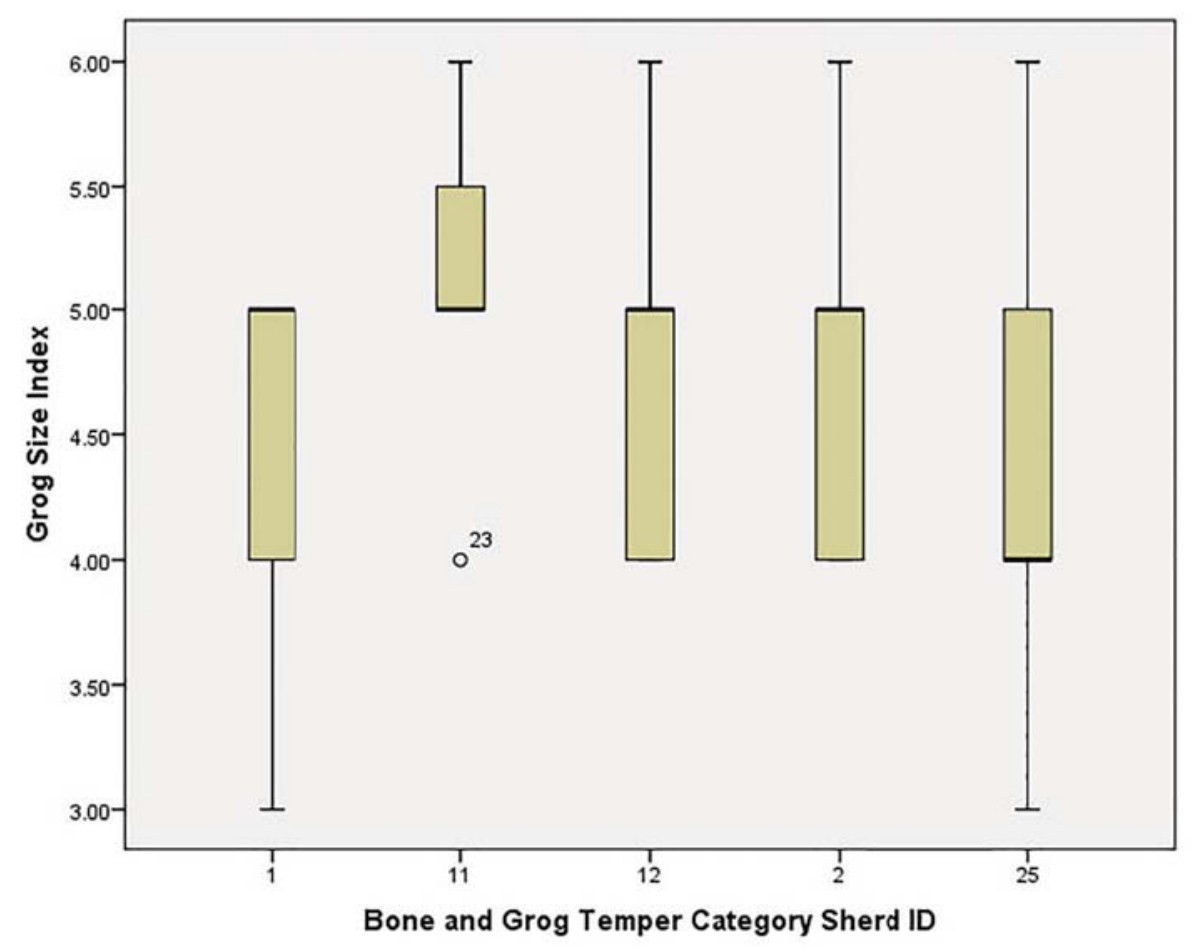

Figure 8. Box plot showing grog size distribution by sherd No. 


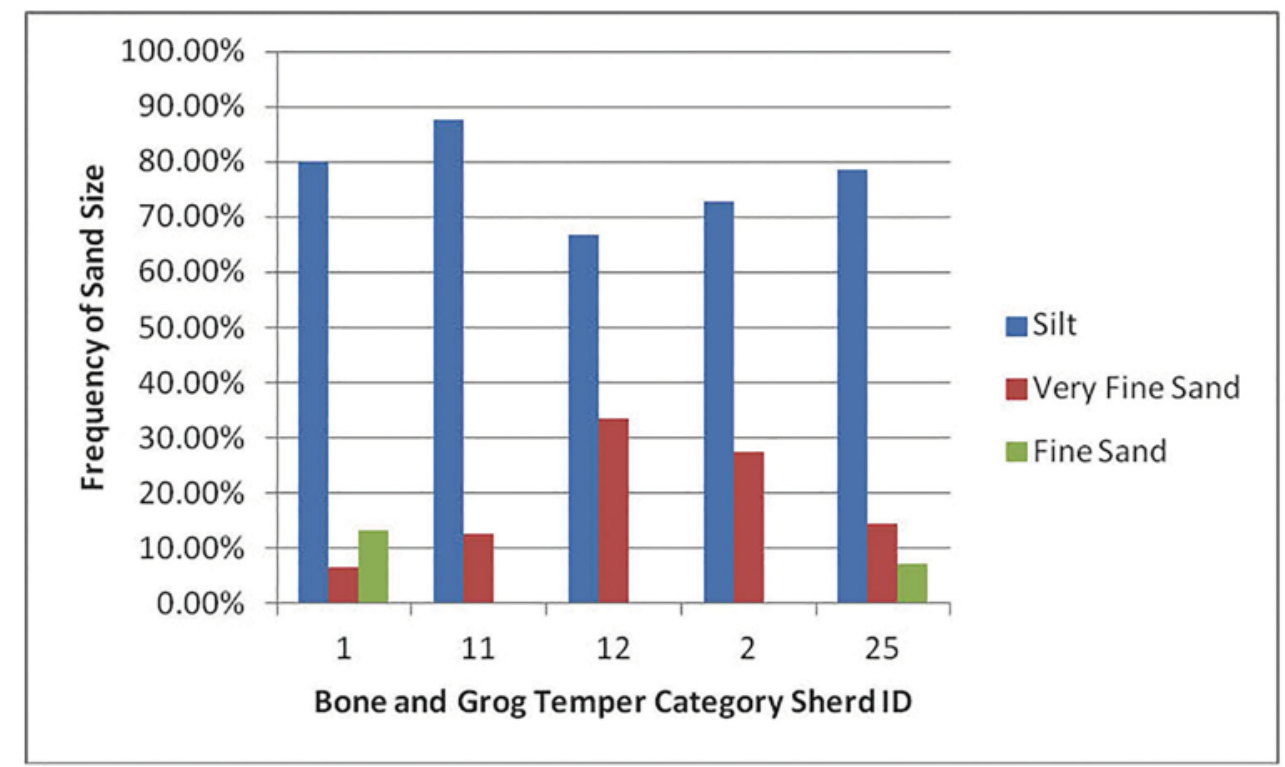

Figure 9. Distribution of the sand size category (based on the Wentworth scale) by sherd No. for bone-grog- tempered sherds.

\section{Sherd No. 1 (Figure 10a)}

Paste Matrix (PPL): Continuous

Paste Color (PPL): 10YR 4/4, dark yellowish brown

B-fabric (XPL): Speckled/Slightly Active

Edge Description: N/A

Grog Description: Generally tempered with bone. Most bone temper was not platy-shaped. Many of the crushed sherds seemed to have the same paste as the thin section.

Comments: Most bone temper was not platy-shaped. Opaques were possibly burnt bone or hematite.

\section{Point Count}

\begin{tabular}{|l|r|r|l|r|r|}
\hline \multicolumn{1}{|c|}{ Paste/Inclusion } & Count & Percent & $\begin{array}{c}\text { Simplified Inclusion } \\
\text { Category }\end{array}$ & Count & Percent \\
\hline Paste & 200 & $66.2 \%$ & Paste & 200 & $69.9 \%$ \\
\hline Bone & 63 & $20.9 \%$ & Sand & 15 & $5.2 \%$ \\
\hline Grog & 5 & $1.7 \%$ & Bone & 63 & $22.0 \%$ \\
\hline Quartz & 14 & $4.6 \%$ & Grog & 5 & $1.8 \%$ \\
\hline Alkali feldspar & 1 & $0.3 \%$ & Other & 286 & $1.1 \%$ \\
\hline Opaque & 3 & $1.0 \%$ & Total & & \\
\hline Voids & 16 & $5.3 \%$ & & & \\
\hline Total & $\mathbf{3 0 2}$ & & & & \\
\hline
\end{tabular}

Also present: hematite (common), muscovite (uncommon), polycrystalline quartz (uncommon), small mafic mineral (rare)

Percentage of voids that might be missing inclusions: $12.5 \%$ 
Inclusion Size (mm)

\begin{tabular}{|l|c|c|c|c|}
\hline & Range & Mean & Median & $\begin{array}{c}\text { Interquartile } \\
\text { Range }\end{array}$ \\
\hline Sand & $.02-.16$ & .06 & .04 & .04 \\
\hline Bone & $.04-1.90$ & .52 & .40 & .54 \\
\hline Grog & $.18-.94$ & .56 & .58 & .48 \\
\hline All Inclusions & $.02-1.90$ & .43 & .32 & .55 \\
\hline
\end{tabular}
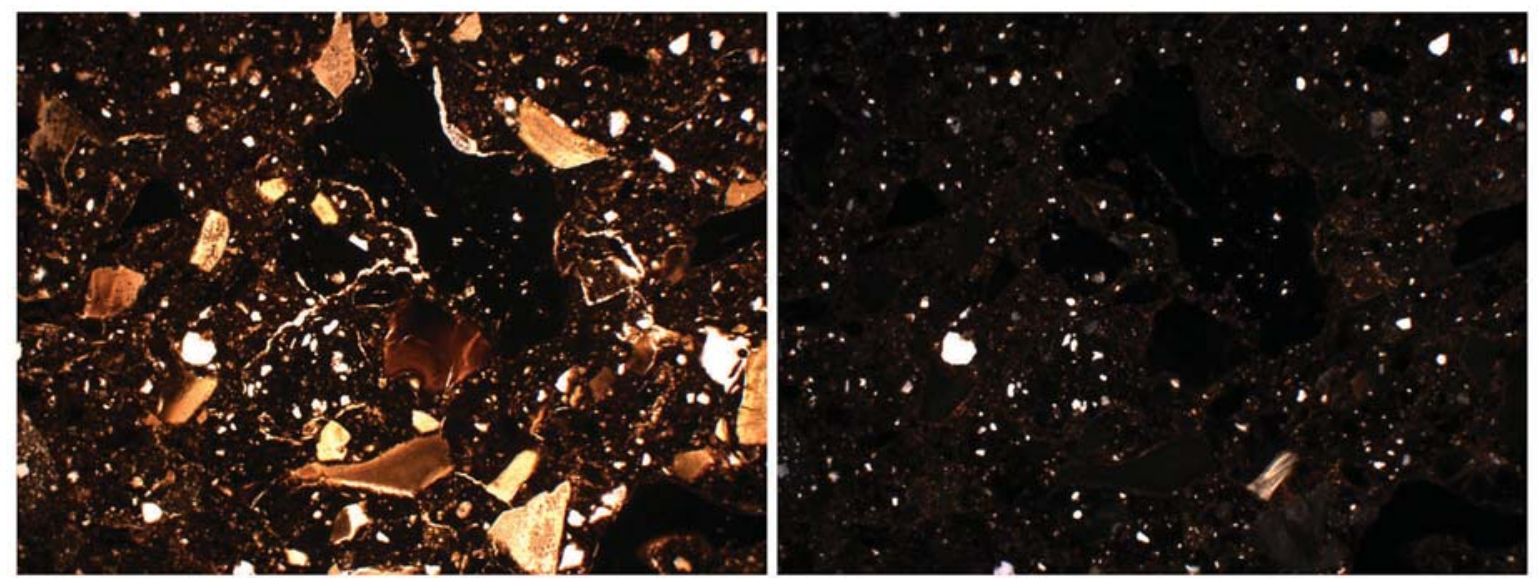

Figure 10a.
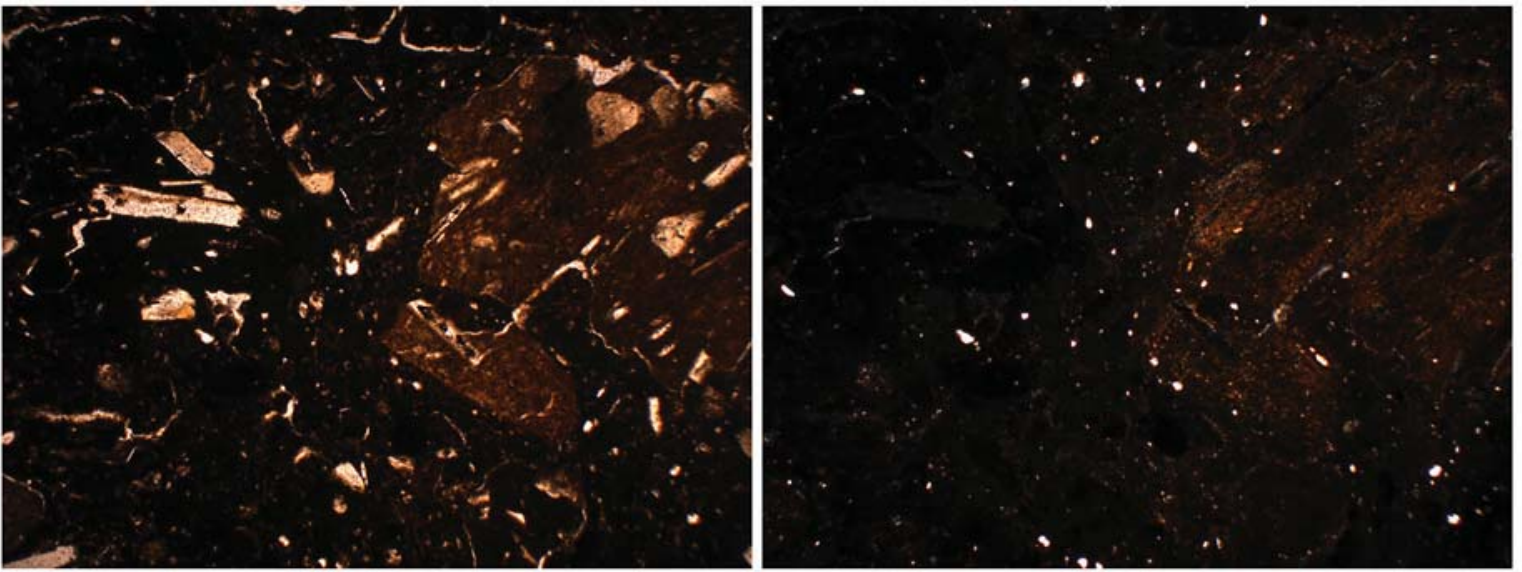

Figure 10b.
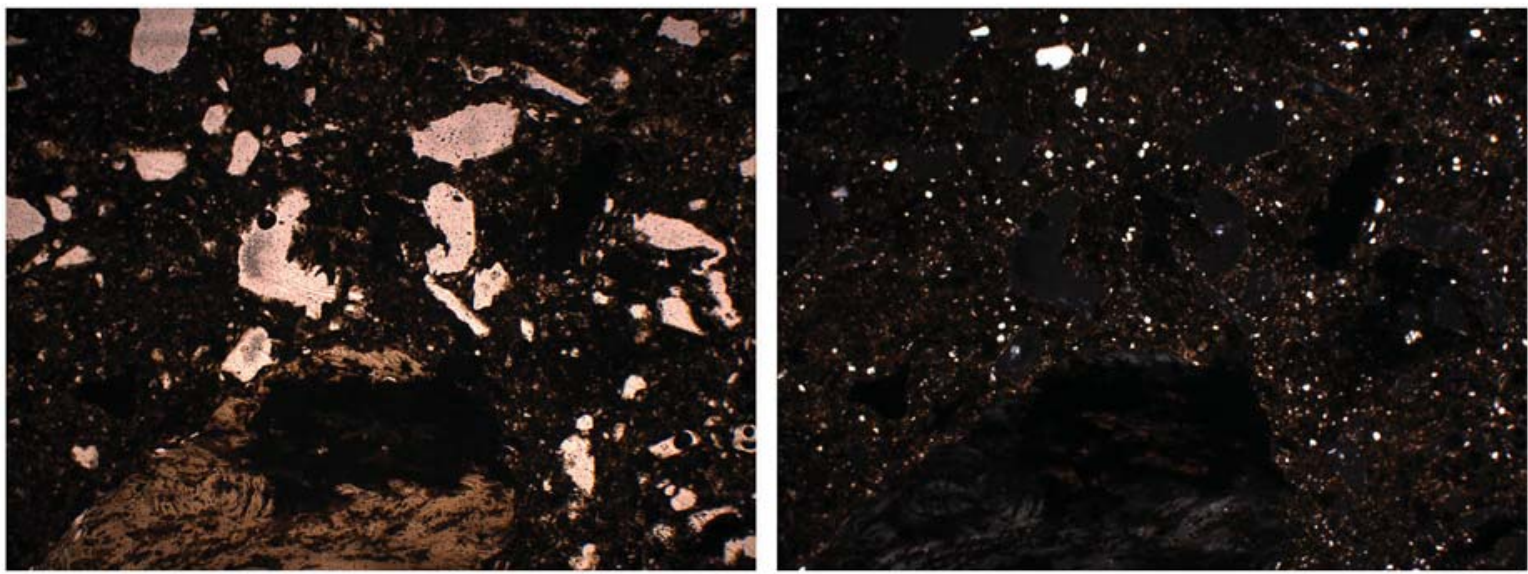

Figure 10c. 

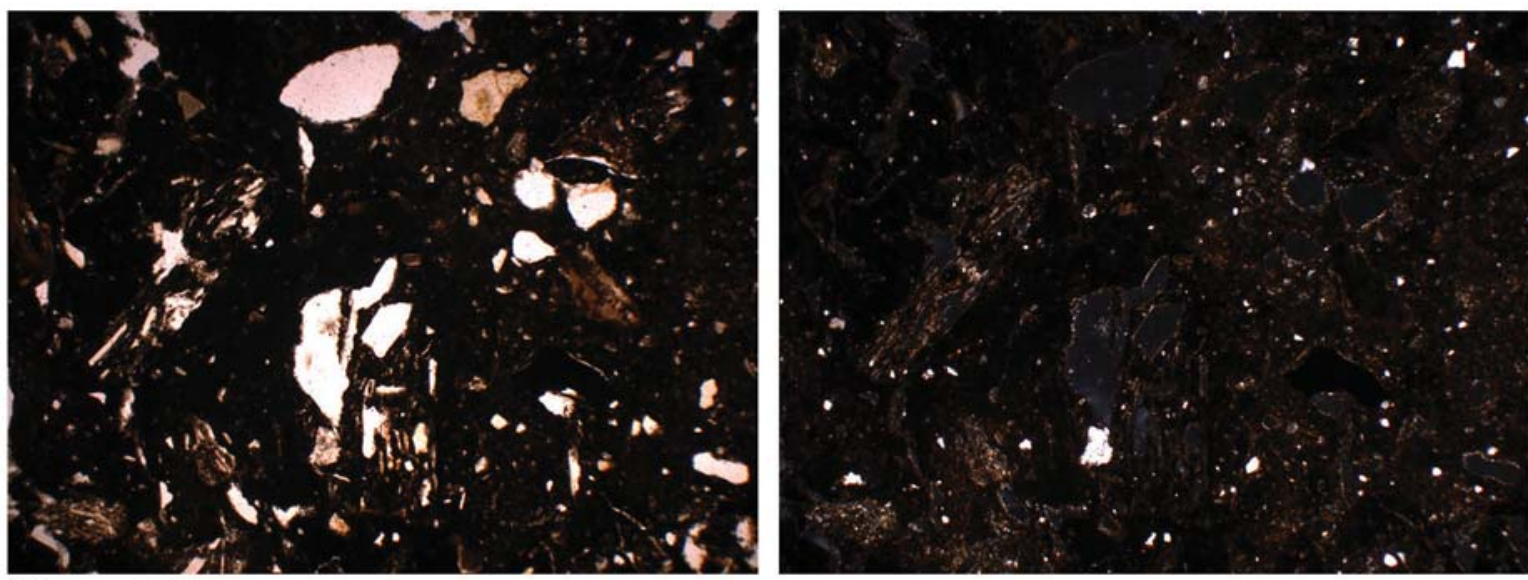

Figure 10d.
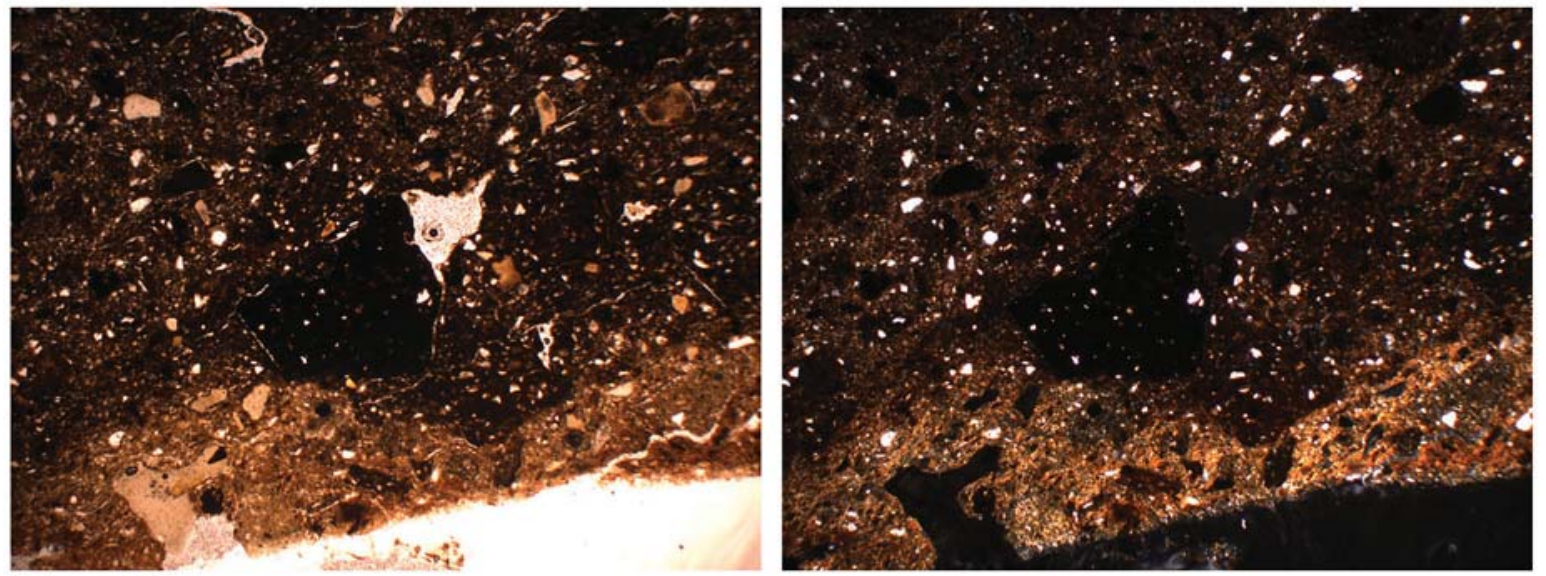

Figure 10e.

Figure 10. Photographs of bone-grog-tempered thin sections: a, No. 1; b, No. 2; c, No. 11; d, No. 12; e, No. 25. All photographs are at $4 \mathrm{x}$ magnification. The plane light image is on the right and the cross-polar light image is on the left.

\section{Sherd No. 2 (Figure 10b)}

Paste Matrix (PPL): Mottled

Paste Color (PPL): 2.5Y 5/4, light olive brown with spots of 2.5Y 3/3, dark olive brown

B-fabric (XPL): Speckled/Slightly Active - dark spots undifferentiated

Edge Description: N/A

Grog Description: Generally tempered with bone/shell or sand. Bone/shell temper is mostly platy. Many of the crushed sherds have the same paste as the thin section.

Comments: Secondary calcite maybe an artifact of the thin section production. 
Point Count

\begin{tabular}{|l|r|r|l|r|r|}
\hline \multicolumn{1}{|c|}{ Paste/Inclusion } & Count & Percent & $\begin{array}{c}\text { Simplified Inclusion } \\
\text { Category }\end{array}$ & Count & Percent \\
\hline Paste & 200 & $82.3 \%$ & Paste & 200 & $88.5 \%$ \\
\hline Grog & 14 & $5.8 \%$ & Sand & 11 & $4.9 \%$ \\
\hline Quartz & 9 & $3.7 \%$ & Grog & 14 & $6.2 \%$ \\
\hline Alkali feldspar & 2 & $0.8 \%$ & Mica & 226 & $0.4 \%$ \\
\hline Muscovite & 1 & $0.4 \%$ & Total & & \\
\hline Voids & $25.2 \%$ & & & \\
\hline Secondary calcite & 2 & $0.8 \%$ & & & \\
\hline Total & $\mathbf{2 4 3}$ & & & \\
\hline
\end{tabular}

Also present: bone (common), hematite (common)

Percentage of voids that might be missing inclusions: $33.3 \%$

Inclusion Size (mm)

\begin{tabular}{|l|c|c|c|c|}
\hline & Range & Mean & Median & $\begin{array}{c}\text { Interquartile } \\
\text { Range }\end{array}$ \\
\hline Sand & $.02-.12$ & 06 & .04 & .08 \\
\hline Grog & $.26-1.50$ & .72 & .65 & .63 \\
\hline All Inclusions & $.02-1.50$ & .41 & .26 & .66 \\
\hline
\end{tabular}

\section{Sherd No. 11 (Figure 10c)}

Paste Matrix (PPL): Continuous

Paste Color (PPL): 2.5Y 5/4, light olive brown

$B$-fabric (XPL): Speckled/Slightly Active

Edge Description: N/A

Grog Description: Generally tempered with bone or possibly shell. Several of the crushed sherds had inclusions with platy structure.

Comments: Most visible bone and possible missing inclusions were not platy-shaped. Opaque might be burnt bone.

Point Count

\begin{tabular}{|l|r|r|l|r|r|}
\hline \multicolumn{1}{|c|}{ Paste/Inclusion } & Count & Percent & $\begin{array}{c}\text { Simplified Inclusion } \\
\text { Category }\end{array}$ & Count & Percent \\
\hline Paste & 200 & $78.4 \%$ & Paste & 200 & $87.3 \%$ \\
\hline Bone & 4 & $1.6 \%$ & Sand & 16 & $7.0 \%$ \\
\hline Grog & 8 & $3.1 \%$ & Bone & 4 & $1.8 \%$ \\
\hline Quartz & 15 & $5.9 \%$ & Grog & 8 & $3.5 \%$ \\
\hline Polycrystalline quartz & 1 & $0.4 \%$ & Other & 229 & $0.4 \%$ \\
\hline Opaque & 1 & $0.4 \%$ & Total & & \\
\hline Voids & 26 & $10.2 \%$ & & & \\
\hline Total & $\mathbf{2 5 5}$ & & & \\
\hline
\end{tabular}

Also present: muscovite (common), alkali feldspar (uncommon), shell (uncommon), charcoal (rare)

Percentage of voids that might be missing inclusions: $76.9 \%$

Inclusion Size (mm)

\begin{tabular}{|l|c|c|c|c|}
\hline & Range & Mean & Median & $\begin{array}{c}\text { Interquartile } \\
\text { Range }\end{array}$ \\
\hline Sand & $.02-.08$ & .04 & .04 & .04 \\
\hline Bone & $.06-.18$ & .12 & .11 & .12 \\
\hline Grog & $.46-1.14$ & .79 & .75 & .44 \\
\hline All Inclusions & $.02-1.14$ & .26 & .06 & .47 \\
\hline
\end{tabular}




\section{Sherd No. 12 (Figure 10d)}

Paste Matrix (PPL): Continuous

Paste Color (PPL): 2.5Y 4/4, olive brown

B-fabric (XPL): Speckled/Slightly Active

Edge Description: N/A

Grog Description: Generally tempered with bone or sand. Several of the crushed sherds had platy-shaped bone temper.

Comments: Bone in thin section not platy-shaped.

\section{Point Count}

\begin{tabular}{|l|r|r|l|r|r|}
\hline \multicolumn{1}{|c|}{ Paste/Inclusion } & Count & \multicolumn{1}{c|}{ Percent } & $\begin{array}{c}\text { Simplified Inclusion } \\
\text { Category }\end{array}$ & Count & Percent \\
\hline Paste & 200 & $81.6 \%$ & Paste & 200 & $85.5 \%$ \\
\hline Bone & 14 & $5.7 \%$ & Sand & 6 & $2.6 \%$ \\
\hline Grog & 13 & $5.3 \%$ & Bone & 14 & $6.0 \%$ \\
\hline Quartz & 6 & $2.4 \%$ & Grog & 13 & $5.6 \%$ \\
\hline Opaque & 1 & $0.4 \%$ & Other & 1 & $0.4 \%$ \\
\hline Voids & 11 & $4.5 \%$ & Total & & \\
\hline Total & $\mathbf{2 4 5}$ & & & & \\
\hline
\end{tabular}

Also present: alkali feldspar (common), polycrystalline quartz (common), plagioclase (uncommon), muscovite (uncommon), charcoal (rare)

Percentage of voids that might be missing inclusions: $72.7 \%$

Inclusion Size (mm)

\begin{tabular}{|l|c|c|c|c|}
\hline & Range & Mean & Median & $\begin{array}{c}\text { Interquartile } \\
\text { Range }\end{array}$ \\
\hline Sand & $.02-.12$ & .06 & .05 & .07 \\
\hline Bone & $.08-1.38$ & .55 & .42 & .77 \\
\hline Grog & $.28-1.80$ & .84 & .72 & .74 \\
\hline All Inclusions & $.02-1.80$ & .56 & .43 & .77 \\
\hline
\end{tabular}

\section{Sherd No. 25 (Figure 10e)}

Paste Matrix (PPL): Continuous (core)

Paste Color (PPL): 10YR 5/6, yellowish brown

$B$-fabric (XPL): Speckled/Slightly Active

Edge Description: Edges are lighter (2.5Y 7/8, yellow) and more active in XPL, but have the same inclusions as the rest of the paste

Grog Description: Generally tempered with sand, bone, or grog. Bone in crushed sherds is not platy-shaped.

Comments: Muscovite is very common. Bone is not platy-shaped. Hematite is present.

\section{Point Count}

\begin{tabular}{|l|r|r|l|r|r|}
\hline \multicolumn{1}{|c|}{ Paste/Inclusion } & Count & \multicolumn{1}{c|}{ Percent } & $\begin{array}{c}\text { Simplified Inclusion } \\
\text { Category }\end{array}$ & Count & Percent \\
\hline Paste & 200 & $78.1 \%$ & Paste & 200 & $81.3 \%$ \\
\hline Bone & 12 & $4.7 \%$ & Sand & 14 & $5.7 \%$ \\
\hline Grog & 18 & $7.0 \%$ & Bone & 12 & $4.9 \%$ \\
\hline Quartz & 13 & $5.1 \%$ & Grog & 18 & $7.3 \%$ \\
\hline Polycrystalline quartz & 1 & $0.4 \%$ & Mica & 2 & $0.8 \%$ \\
\hline Muscovite & 2 & $0.8 \%$ & Total & $\mathbf{2 4 6}$ & \\
\hline Voids & 10 & $3.9 \%$ & & & \\
\hline Total & $\mathbf{2 5 6}$ & & & & \\
\hline
\end{tabular}


Also present: perthite (rare), alkali feldspar (common), small mafic mineral (augite) (rare)

Percentage of voids that might be missing inclusions: $40 \%$

Inclusion Size (mm)

\begin{tabular}{|l|c|c|c|c|}
\hline & Range & Mean & Median & $\begin{array}{c}\text { Interquartile } \\
\text { Range }\end{array}$ \\
\hline Sand & $.02-.18$ & .06 & .04 & .03 \\
\hline Bone & $.06-1.80$ & .39 & .21 & .50 \\
\hline Grog & $.14-1.32$ & .48 & .35 & .42 \\
\hline All Inclusions & $.02-1.80$ & .31 & .18 & .35 \\
\hline
\end{tabular}

\section{Grog Temper}

The grog temper category was based on the presence of grog without bone or shell inclusions.

However, it should be noted that thin section No. 5 did have one piece of bone sampled during point counting. As bone temper in this thin section was very rare, it was placed in this category. Also thin section No. 21 may be bone and grog tempered; however, no bone was observed in the thin section, yet there were several voids that could possibly be bone based on their shape. The grog temper category represented $26.1 \%$ of the samples ( $n=6)$, all from the Spiro site (see Table 4).

The percentage of grog in this category ranged from $1.9 \%$ to $7.7 \%$. Figure 11 is a box plot showing the distribution of grog size based on the size index. While all of the thin sections in the bone and grog temper category had grog (crushed sherds) with bone/shell inclusions, in the grog temper category, only three thin sections (No. 5, No. 21, and No. 27) had crushed sherds with bone/shell. Only two (No. 21 and No. 27) thin sections had crushed sherd with platy bone/shell inclusions. The remaining thin sections contained crushed sherds with sand (No. 3 and No. 15) and sand and grog (No. 23).

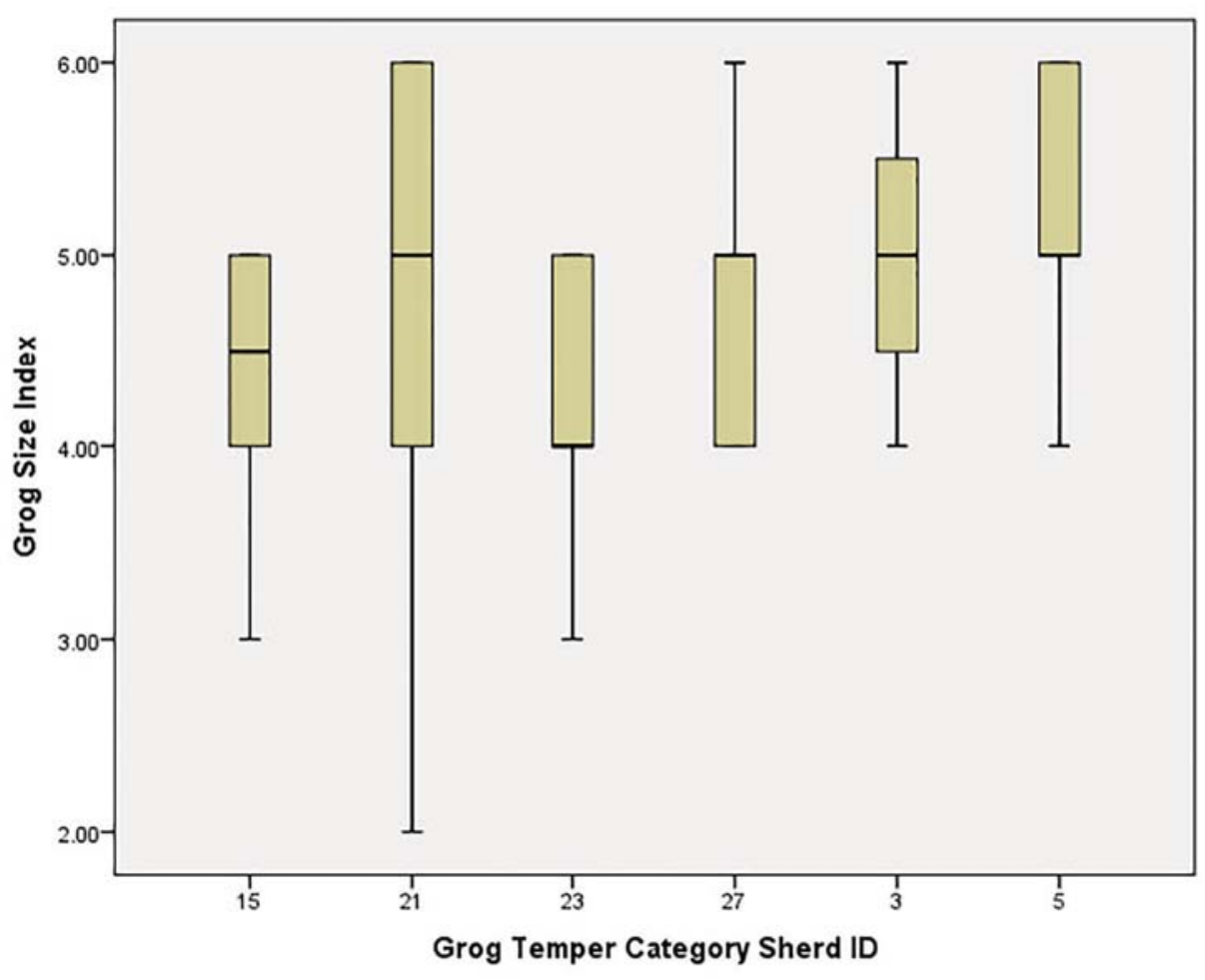

Figure 11. Box plot of the size index for grog by sherd No. for grog-tempered sherds. 
The percentage of sand in the grog-tempered thin sections ranged from $2.8 \%$ to $10.9 \%$. Figure 12 shows the sand size distribution based on the Wentworth scale. Although there is a greater range of sand sizes in this temper category, the majority of the sand is silt size suggesting that the sand was a natural inclusion in the clay.

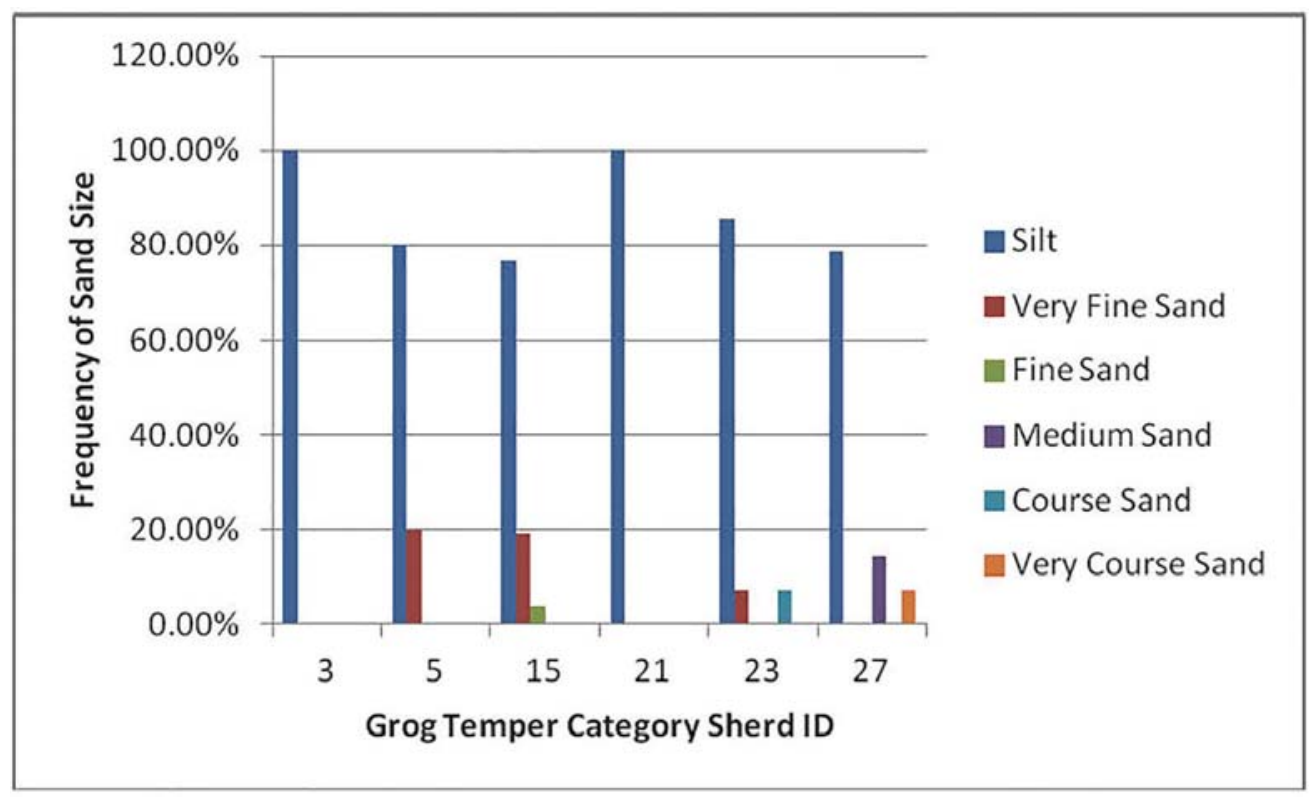

Figure 12. Distribution of sand size based on the Wentworth scale for the grog-tempered sherds.

\section{Sherd No. 3 (Figure 13a)}

Paste Matrix (PPL): Continuous

Paste Color (PPL): 7.5YR 6/8, reddish yellow

B-fabric (XPL): Speckled/Slightly Active

Edge Description: N/A

Grog Description: Generally tempered with sand. Similar paste as thin section.

Comments: Few inclusions

\section{Point Count}

\begin{tabular}{|l|r|r|l|r|r|}
\hline \multicolumn{1}{|c|}{ Paste/Inclusion } & Count & Percent & $\begin{array}{c}\text { Simplified Inclusion } \\
\text { Category }\end{array}$ & Count & Percent \\
\hline Paste & 200 & $88.5 \%$ & Paste & 200 & $94.8 \%$ \\
\hline Grog & 4 & $1.8 \%$ & Sand & 6 & $2.8 \%$ \\
\hline Quartz & 6 & $2.7 \%$ & Grog & 4 & $1.9 \%$ \\
\hline Hematite & 1 & $0.4 \%$ & Other & 1 & $0.5 \%$ \\
\hline Voids & 15 & $6.6 \%$ & Total & $\mathbf{2 1 1}$ & \\
\hline Total & $\mathbf{2 2 6}$ & & & & \\
\hline
\end{tabular}

Also present: muscovite (uncommon), polycrystalline quartz (rare)

Percentage of voids that might be missing inclusions: $13.3 \%$

Inclusion Size (mm)

\begin{tabular}{|l|c|c|c|c|}
\hline & Range & Mean & Median & $\begin{array}{c}\text { Interquartile } \\
\text { Range }\end{array}$ \\
\hline Sand & $.02-.06$ & .03 & .02 & .03 \\
\hline Grog & $.36-1.02$ & .76 & .83 & .55 \\
\hline All Inclusions & $.02-1.02$ & .30 & .06 & .70 \\
\hline
\end{tabular}



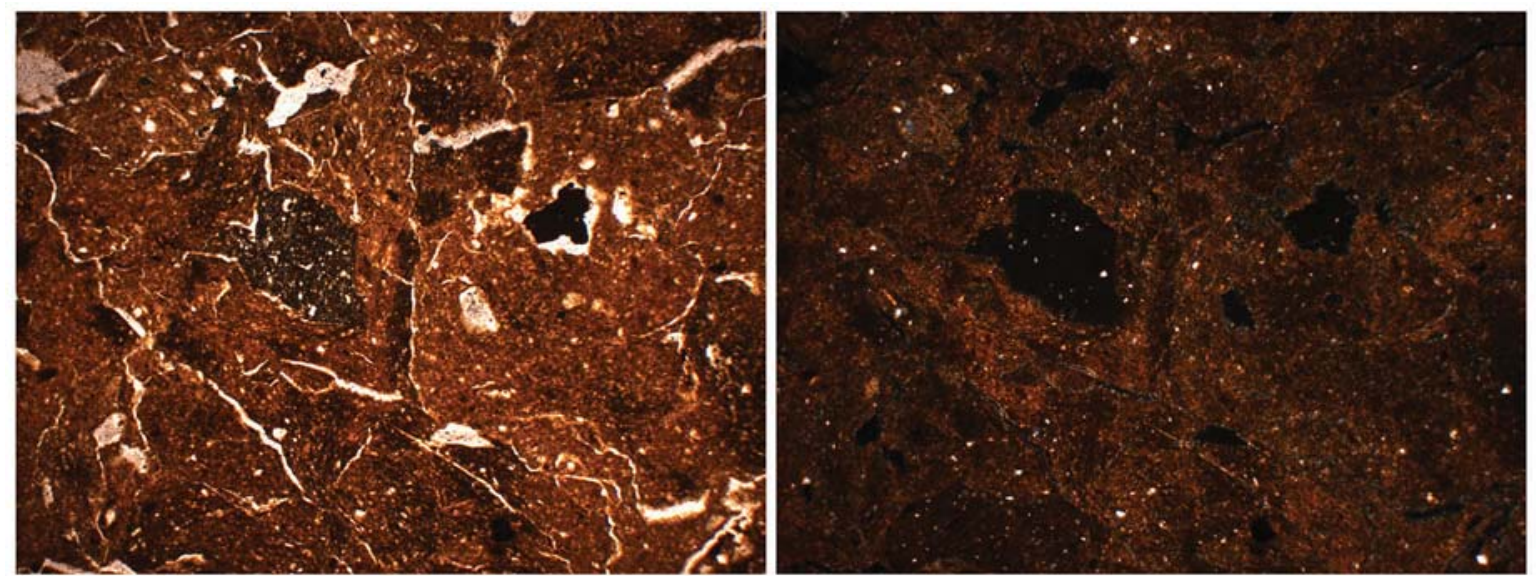

Figure 13a.
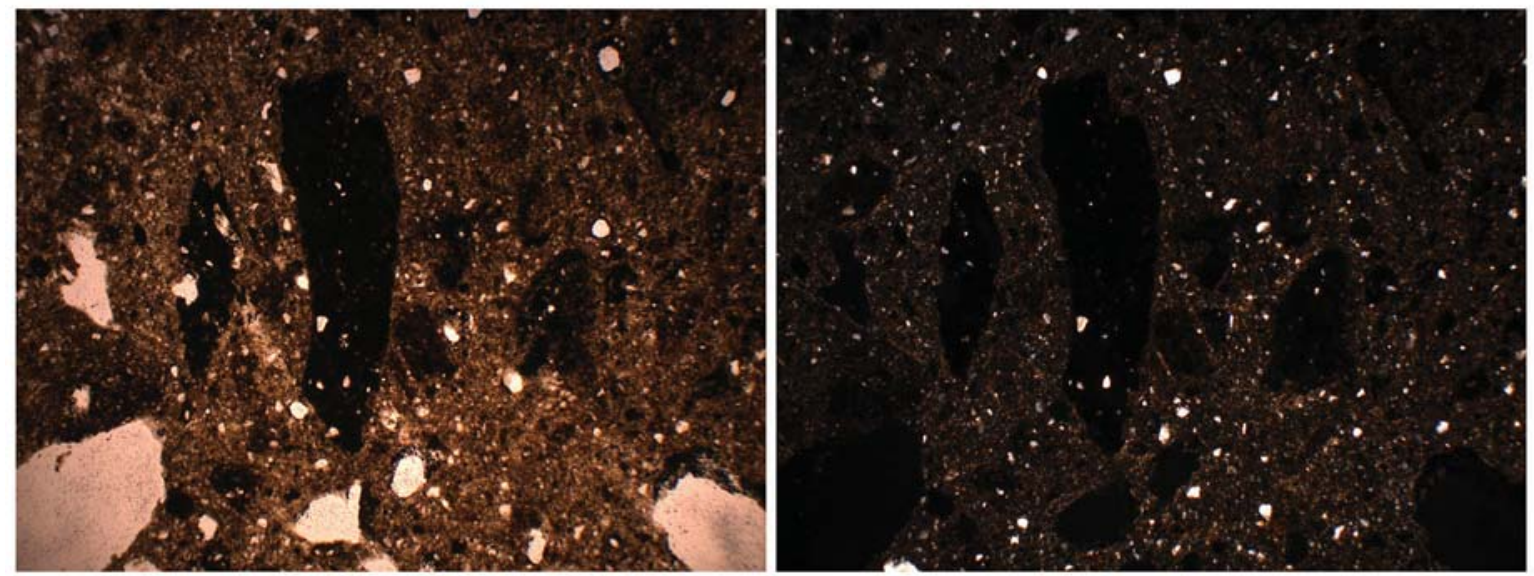

Figure 13b.
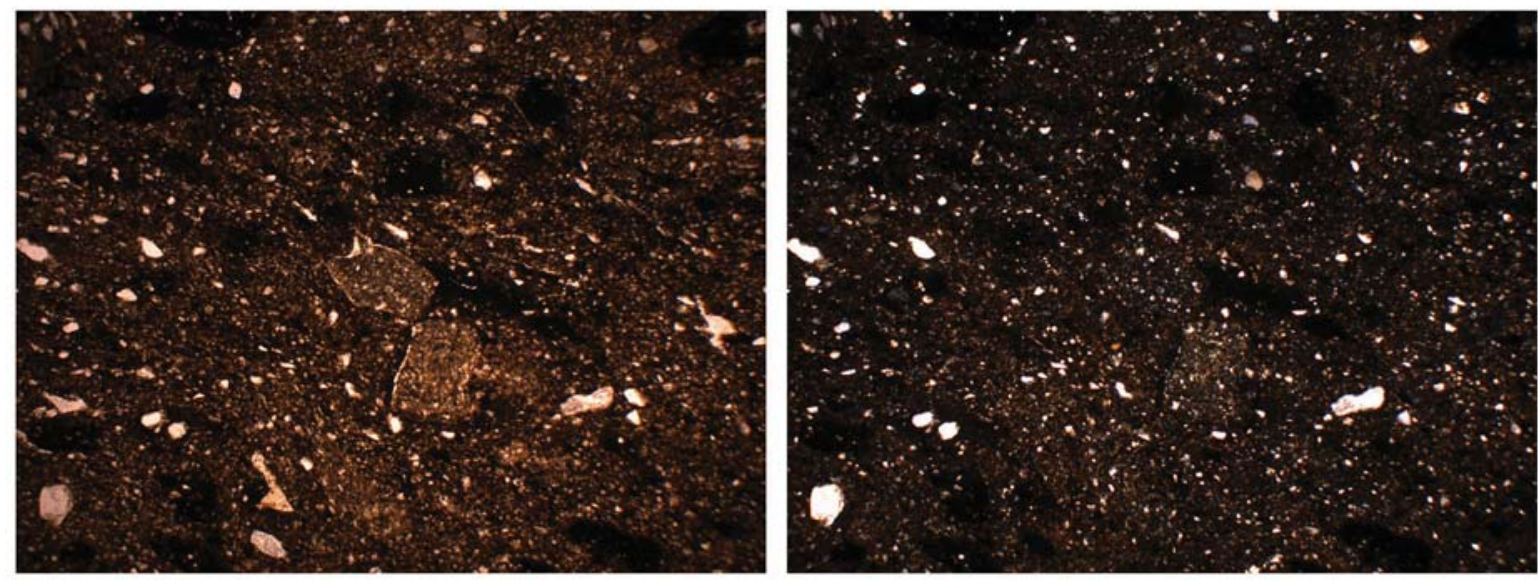

Figure 13c. 

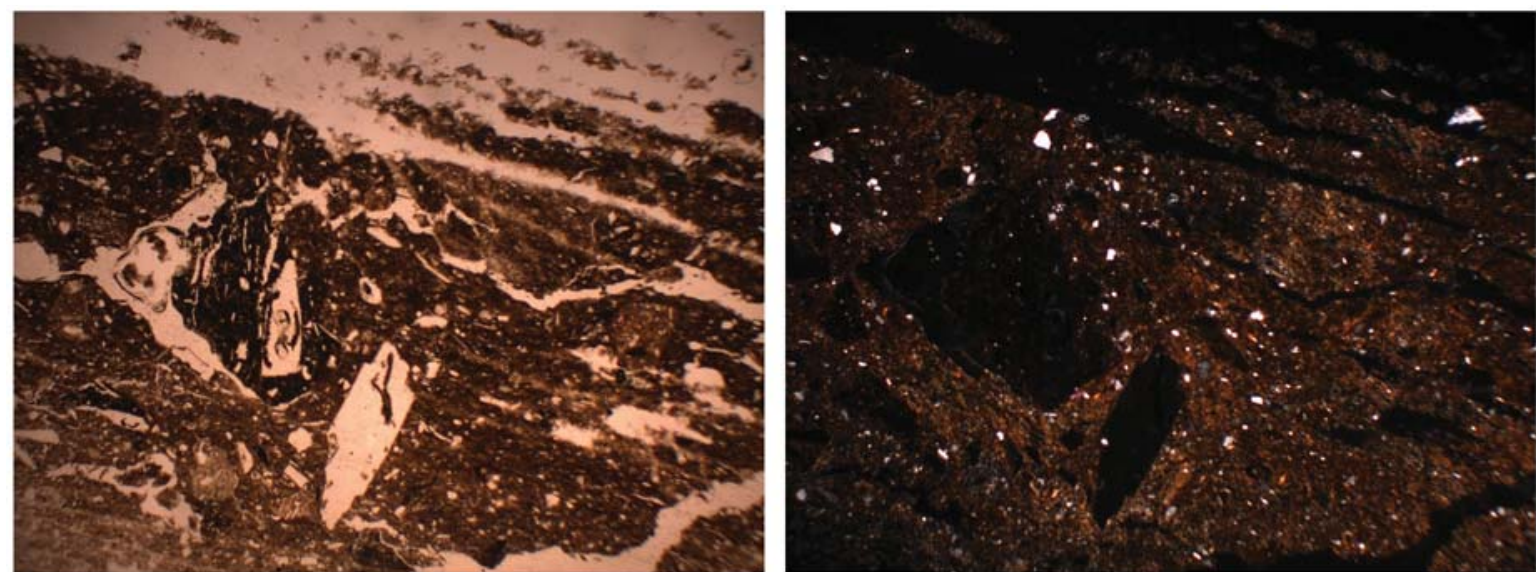

Figure 13d.
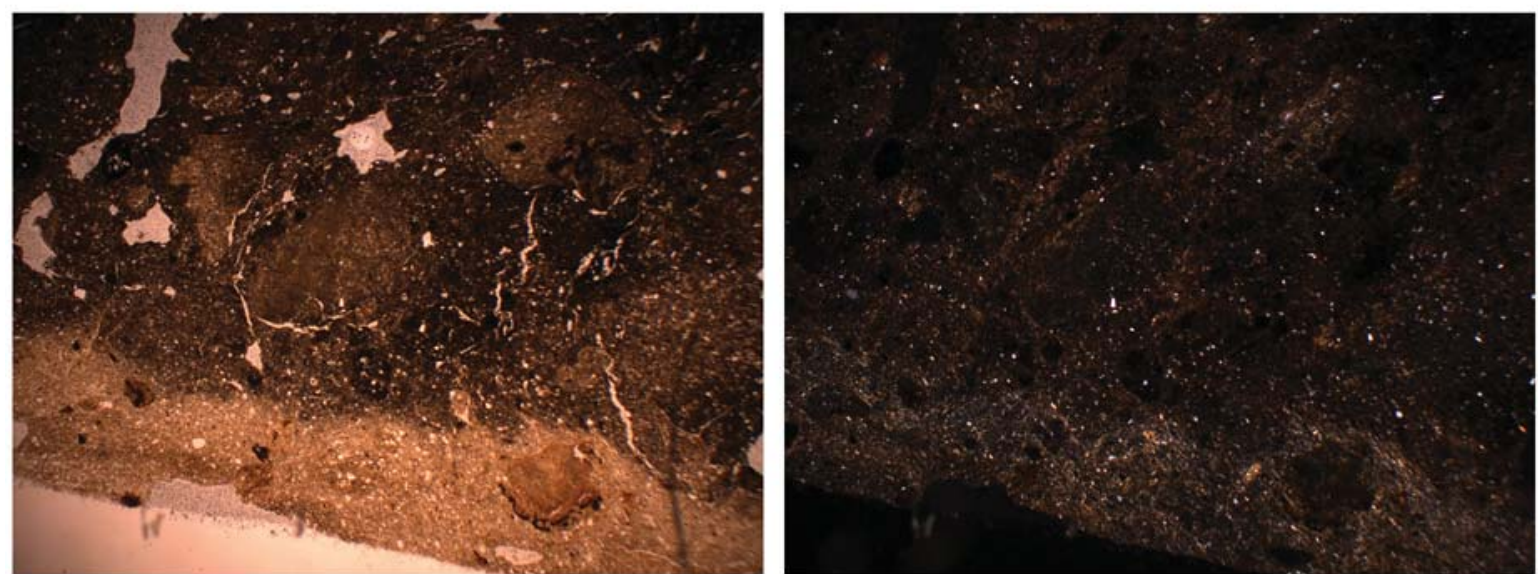

Figure 13e.
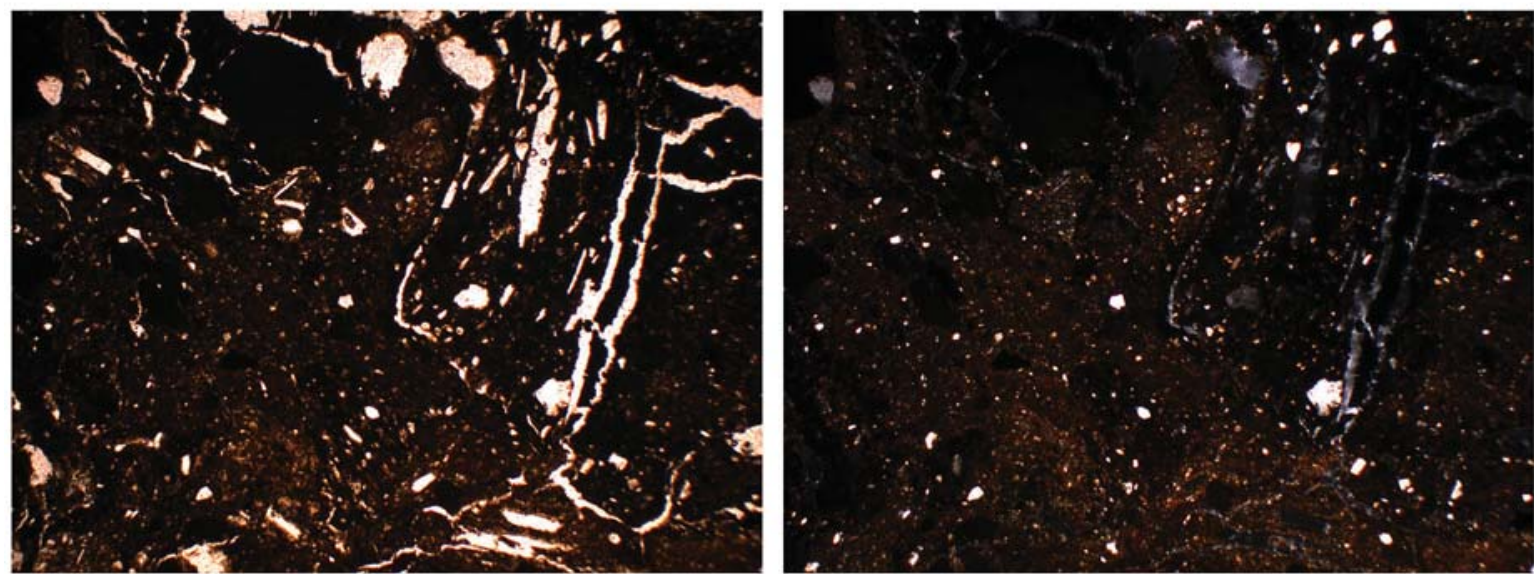

\section{Figure 13f.}

Figure 13. Photographs of grog-tempered thin sections: a, No. 3; b, No. 5; c, No. 15; d, No. 21; e, No. 23; f, No. 27. All photographs are at $4 \mathrm{x}$ magnification. The plane light image is on the right and the crosspolar light image is on the left. 


\section{Sherd No. 5 (Figure 13b)}

Paste Matrix (PPL): Continuous

Paste Color (PPL): 2.5Y 7/6, yellow

$B$-fabric (XPL): Speckled/Slightly Active

Edge Description: N/A

Grog Description: Generally tempered with sand or bone (bone is not platy).

Comments: Missing inclusions might be sand or grog. Bone is not common in the thin section. Muscovite is present.

\section{Point Count}

\begin{tabular}{|l|r|r|l|r|r|}
\hline \multicolumn{1}{|c|}{ Paste/Inclusion } & Count & \multicolumn{1}{c|}{ Percent } & $\begin{array}{l}\text { Simplified Inclusion } \\
\text { Category }\end{array}$ & Count & Percent \\
\hline Paste & 200 & $79.4 \%$ & Paste & 200 & $88.1 \%$ \\
\hline Bone & 1 & $0.4 \%$ & Sand & 15 & $6.6 \%$ \\
\hline Grog & 10 & $4.0 \%$ & Bone & 1 & $0.4 \%$ \\
\hline Quartz & 13 & $5.2 \%$ & Grog & 10 & $4.4 \%$ \\
\hline Alkali feldspar & 1 & $0.4 \%$ & Mica & 1 & $0.4 \%$ \\
\hline Muscovite & 1 & $0.4 \%$ & Total & $\mathbf{2 2 7}$ & \\
\hline Chert & 1 & $0.4 \%$ & & & \\
\hline Voids & 25 & $9.9 \%$ & & & \\
\hline Total & $\mathbf{2 5 2}$ & & & & \\
\hline
\end{tabular}

Also present: hematite (common), polycrystalline quartz (common)

Percentage of voids that might be missing inclusions: $60 \%$

\section{Inclusion Size (mm)}

\begin{tabular}{|l|c|c|c|c|}
\hline & Range & Mean & Median & $\begin{array}{c}\text { Interquartile } \\
\text { Range }\end{array}$ \\
\hline Sand & $.02-.12$ & .05 & .04 & .04 \\
\hline Grog & $.48-1.52$ & .91 & .85 & .56 \\
\hline All Inclusions & $.02-1.52$ & .37 & .06 & .68 \\
\hline
\end{tabular}

\section{Sherd No. 15 (Figure 13c)}

Paste Matrix (PPL): Mottled

Paste Color (PPL): 2.5Y 6/6, olive yellow with spots of $2.5 Y$ 3/3, dark olive brown

$B$-fabric (XPL): Speckled/Slightly Active (very slight)

Edge Description: On one side there are some dark red spots (approximately $0.06 \mathrm{~mm}$ thick) along the edge (possible artifact of thin section production).

Grog Description: Generally sand-tempered. The paste is the same as the paste in the thin section.

Comments: Clay pellets are discrete dark reddish-brown to black inclusions with little sand: possible hematite or grog. Muscovite is present. 
Point Count

\begin{tabular}{|l|r|r|l|r|r|}
\hline \multicolumn{1}{|c|}{ Paste/Inclusion } & Count & Percent & $\begin{array}{c}\text { Simplified Inclusion } \\
\text { Category }\end{array}$ & Count & Percent \\
\hline Paste & 200 & $82.0 \%$ & Paste & 200 & $84.0 \%$ \\
\hline Sherd & 8 & $3.3 \%$ & Sand & 26 & $10.9 \%$ \\
\hline Quartz & 23 & $9.4 \%$ & Grog & 8 & $3.4 \%$ \\
\hline Polycrystalline quartz & 2 & $0.8 \%$ & Mica & 3 & $0.4 \%$ \\
\hline Alkali feldspar & 1 & $0.4 \%$ & Other & $\mathbf{2 3 8}$ & $1.3 \%$ \\
\hline Muscovite & 1 & $0.4 \%$ & Total & & \\
\hline Clay pellet & 3 & $1.2 \%$ & & & \\
\hline Voids & 6 & $2.5 \%$ & & & \\
\hline Total & $\mathbf{2 4 4}$ & & & & \\
\hline
\end{tabular}

Also present: plagioclase (rare)

Percentage of voids that might be missing inclusions: 0\%

Inclusion Size (mm)

\begin{tabular}{|l|c|c|c|c|}
\hline & Range & Mean & Median & $\begin{array}{c}\text { Interquartile } \\
\text { Range }\end{array}$ \\
\hline Sand & $.02-.22$ & .06 & .04 & .05 \\
\hline Grog & $.22-.80$ & .52 & .50 & .30 \\
\hline All Inclusions & $.02-1.04$ & .20 & .06 & .35 \\
\hline
\end{tabular}

\section{Sherd No. 21 (Figure 13d)}

Paste Matrix (PPL): Mottled

Paste Color (PPL): 10YR 5/6, yellowish-brown with spots of 10YR 3/4, dark yellowish-brown

B-fabric (XPL): Speckled/Slightly Active

Edge Description: N/A

Grog Description: Generally tempered with bone or shell - most of the inclusions are missing (represented by platy voids)

Comments: The bulk of the thin section is too thin or missing. When point counting, skipped large breaks in the thin section. Several of the voids are platy-shaped - possibly bone. Tiny muscovite is present.

\section{Point Count}

\begin{tabular}{|l|r|r|l|r|r|}
\hline \multicolumn{1}{|c|}{ Paste/Inclusion } & Count & Percent & $\begin{array}{c}\text { Simplified Inclusion } \\
\text { Category }\end{array}$ & Count & Percent \\
\hline Paste & 200 & $82.0 \%$ & Paste & 200 & $89.3 \%$ \\
\hline Sherd & 11 & $4.5 \%$ & Sand & 12 & $5.4 \%$ \\
\hline Quartz & 12 & $4.9 \%$ & Grog & 11 & $4.9 \%$ \\
\hline Muscovite & 1 & $0.4 \%$ & Mica & 224 & $0.4 \%$ \\
\hline Voids & 20 & $8.2 \%$ & Total & & \\
\hline Total & 244 & & & & \\
\hline
\end{tabular}

Also present: hematite (uncommon), microcline (rare)

Percentage of voids that are possibly missing inclusions: $40 \%$

Inclusion Size (mm)

\begin{tabular}{|l|c|c|c|c|}
\hline & Range & Mean & Median & $\begin{array}{c}\text { Interquartile } \\
\text { Range }\end{array}$ \\
\hline Sand & $.02-.06$ & .04 & .04 & .04 \\
\hline Grog & $.08-1.66$ & .84 & .92 & .96 \\
\hline All Inclusions & $.02-1.66$ & .40 & .06 & .81 \\
\hline
\end{tabular}




\section{Sherd No. 23 (Figure 13e)}

Paste Matrix (PPL): Continuous

Paste Color (PPL): 2.5Y 6/4, light yellowish-brown

$B$-fabric (XPL): Speckled/Slightly Active

Edge Description: One edge is lighter (2.5Y 8/4, pale yellow) and more active, but also rubbed a little thin. Grog Description: Generally tempered with sand or grog. Several have the same paste as the thin section. Comments: Opaque possibly burnt (black) bone (rare). Small muscovite pieces very common.

\section{Point Count}

\begin{tabular}{|l|r|r|l|r|r|}
\hline \multicolumn{1}{|c|}{ Paste/Inclusion } & Count & \multicolumn{1}{c|}{ Percent } & $\begin{array}{c}\text { Simplified Inclusion } \\
\text { Category }\end{array}$ & Count & Percent \\
\hline Paste & 200 & $78.7 \%$ & Paste & 200 & $85.1 \%$ \\
\hline Grog & 18 & $7.1 \%$ & Sand & 14 & $6.0 \%$ \\
\hline Quartz & 14 & $5.5 \%$ & Grog & 18 & $7.7 \%$ \\
\hline Muscovite & 1 & $0.4 \%$ & Mica & 2 & $0.9 \%$ \\
\hline Opaque & 1 & $0.4 \%$ & Other & 1 & $0.4 \%$ \\
\hline Biotite & 1 & $0.4 \%$ & Total & $\mathbf{2 3 5}$ & \\
\hline Voids & 19 & $7.48 \%$ & & & \\
\hline Total & $\mathbf{2 5 4}$ & & & & \\
\hline
\end{tabular}

Also present: mica schist (rare), alkali feldspar (rare)

Percentage of voids that might be missing inclusions: $10.5 \%$

Inclusion Size (mm)

\begin{tabular}{|l|c|c|c|c|}
\hline & Range & Mean & Median & $\begin{array}{c}\text { Interquartile } \\
\text { Range }\end{array}$ \\
\hline Sand & $.02-.60$ & .07 & .02 & .02 \\
\hline Grog & $.18-.78$ & .49 & .50 & .26 \\
\hline All Inclusions & $.02-.78$ & .29 & .24 & .50 \\
\hline
\end{tabular}

Sherd No. 27 (Figure 13f)

Paste Matrix (PPL): Mottled with core

Paste Color (PPL): 10YR 5/8, yellowish-brown with spots of 10YR 3/3, dark brown (mostly around voids) core: 10YR 4/4, dark yellowish brown

$B$-fabric (XPL): Speckled/Slightly Active - Core is undifferentiated

Edge Description: Spots of dark red to black run along one edge

Grog Description: Generally tempered with bone or shell (mostly platy voids are seen in crushed sherds)

Comments: Some platy voids running parallel to the rim may be bone.

\section{Point Count}

\begin{tabular}{|l|r|r|l|r|r|}
\hline \multicolumn{1}{|c|}{ Paste/Inclusion } & Count & Percent & $\begin{array}{c}\text { Simplified Inclusion } \\
\text { Category }\end{array}$ & Count & Percent \\
\hline Paste & 200 & $82.3 \%$ & Paste & 200 & $88.1 \%$ \\
\hline Grog & 13 & $5.3 \%$ & Sand & 14 & $6.2 \%$ \\
\hline Quartz & 12 & $4.9 \%$ & Grog & 13 & $5.7 \%$ \\
\hline Polycrystalline quartz & 1 & $0.4 \%$ & Total & $\mathbf{2 2 7}$ & \\
\hline Alkali feldspar & 1 & $0.4 \%$ & & & \\
\hline Voids & 16 & $6.6 \%$ & & & \\
\hline Total & $\mathbf{2 4 3}$ & & & & \\
\hline
\end{tabular}

Also present: muscovite (uncommon), hematite (common), clay pellet (uncommon), bone (rare)

Percentage of voids that might be missing inclusions: $50 \%$ 
Inclusion Size (mm)

\begin{tabular}{|l|c|c|c|c|}
\hline & Range & Mean & Median & $\begin{array}{c}\text { Interquartile } \\
\text { Range }\end{array}$ \\
\hline Sand & $.02-1.12$ & .16 & .04 & .11 \\
\hline Grog & $.40-1.20$ & .74 & .70 & .48 \\
\hline All Inclusions & $.02-1.20$ & .44 & .42 & .72 \\
\hline
\end{tabular}

\section{Grog and Sand Temper}

The grog and sand temper category was distinguished from the grog temper category by the quantity and size of sand in the thin section. Only one thin section from the Spiro site was represented in this group: No. 24. Thin section No. 24 had $14.2 \%$ sand and $16.6 \%$ grog, which is a higher percentage in either inclusion category than any of the thin sections in the grog temper category (see Table 4). In addition, the majority of the sand inclusions were in the fine sand size category ( 0.126 to $0.25 \mathrm{~mm}$ ) (Figure 14). The larger sand particles may suggest that the some of the sand was intentionally added as temper to the clay.

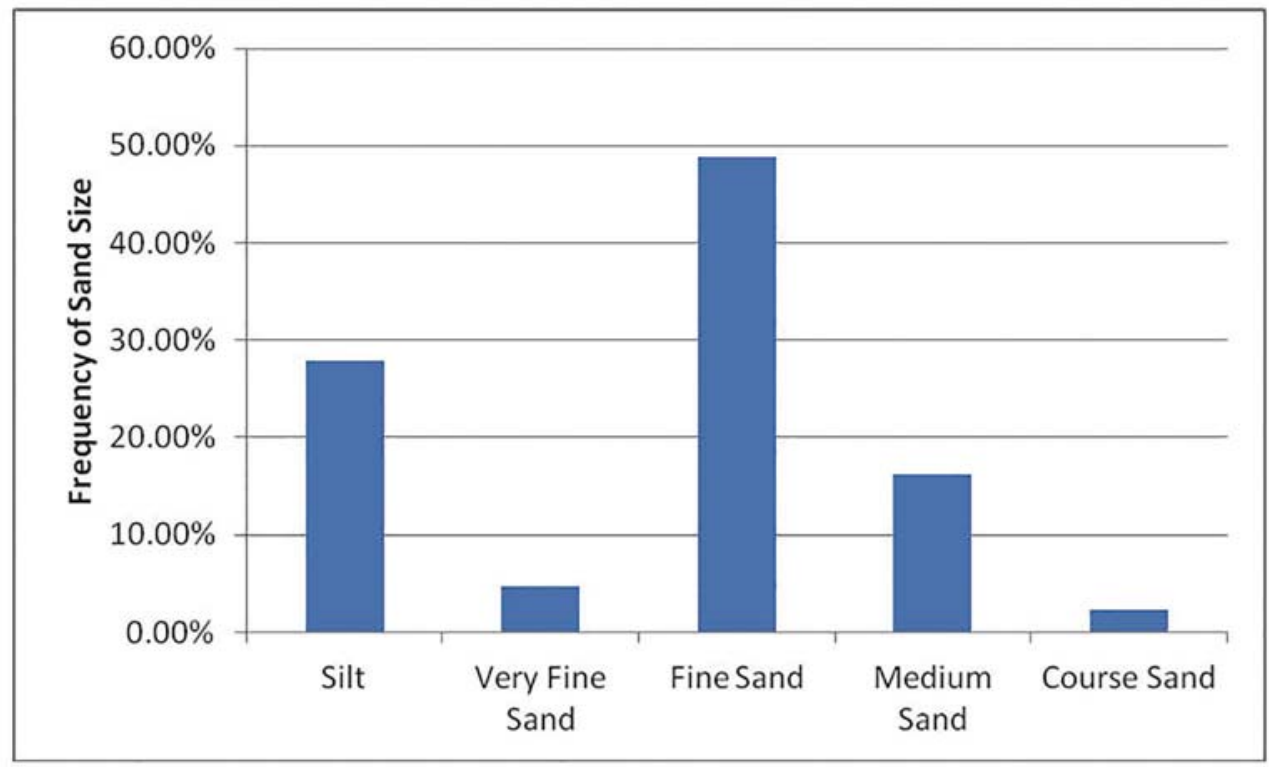

Figure 14. Distribution of sand size based on the Wentworth scale for thin section No. 24 .

\section{Sherd No. 24 (Figure 15)}

Paste Matrix (PPL): Continuous (Core)

Paste Color (PPL): 10YR 5/6, yellowish-brown

B-fabric (XPL): Speckled/Slightly Active

Edge Description: Edges are more active in XPL than core

Grog Description: Generally tempered with sand or grog

Comments: Lots of hematite present. Opaques are most likely hematite. 
Point Count

\begin{tabular}{|l|r|r|l|r|r|}
\hline \multicolumn{1}{|c|}{ Paste/Inclusion } & Count & Percent & $\begin{array}{c}\text { Simplified Inclusion } \\
\text { Category }\end{array}$ & Count & Percent \\
\hline Paste & 200 & $62.5 \%$ & Paste & 200 & $66.2 \%$ \\
\hline Grog & 50 & $15.6 \%$ & Sand & 43 & $14.2 \%$ \\
\hline Quartz & 33 & $10.3 \%$ & Grog & 50 & $16.6 \%$ \\
\hline Polycrystalline quartz & 4 & $1.3 \%$ & Other & $\mathbf{3 0 2}$ & $3.0 \%$ \\
\hline Alkali feldspar & 6 & $1.9 \%$ & Total & & \\
\hline Clay pellet & 1 & $0.3 \%$ & & & \\
\hline Opaque & 8 & $2.5 \%$ & & & \\
\hline Voids & 18 & $5.6 \%$ & & & \\
\hline Total & $\mathbf{3 2 0}$ & & & & \\
\hline
\end{tabular}

Also present: bone (rare)

Percentage of voids that might be missing inclusions: $0 \%$

Inclusion Size (mm)

\begin{tabular}{|l|c|c|c|c|}
\hline & Range & Mean & Median & $\begin{array}{c}\text { Interquartile } \\
\text { Range }\end{array}$ \\
\hline Sand & $.02-.58$ & .17 & .18 & .20 \\
\hline Grog & $.10-1.64$ & .45 & .39 & .27 \\
\hline All Inclusions & $.02-1.64$ & .31 & .26 & .27 \\
\hline
\end{tabular}
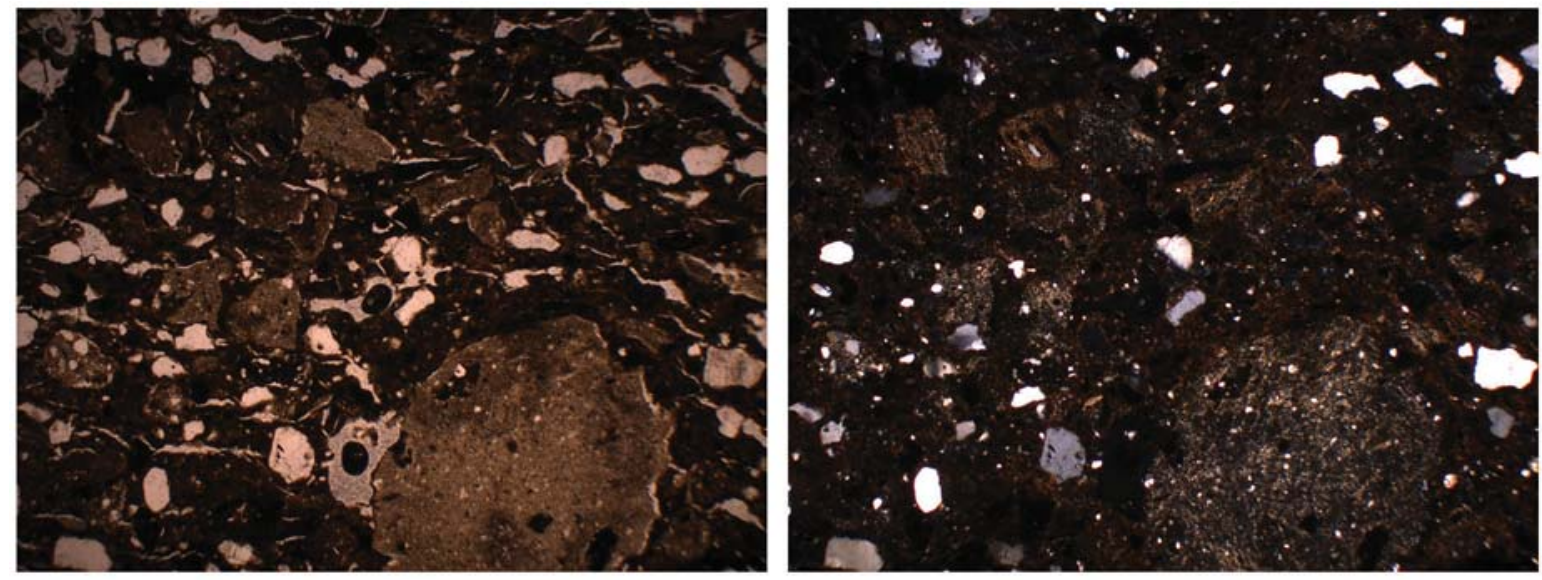

Figure 15.

Figure 15. Photographs of grog-sand tempered thin section No. 24. All photographs are at 4x magnification. The plane light image is on the right and the cross-polar light image is on the left.

\section{Shell Temper}

The shell temper category was based on the presence of shell without bone or grog. The shell temper category represented $17.4 \%$ of the thin sections, including three sherds from the Spiro site (No. 10, No. 18, and No. 20) and one sherd from the Moore \#3 site (No. 29, see description below). The percentage of shell in this temper category ranged from $10.9 \%$ to $35.8 \%$. A box plot of the shell size distribution by sherd No. is shown in Figure 16. With the exception of thin section No. 10, the shell is commonly platy-shaped (Figure 17). Given the difference in percentage, size, and shape of the shell, thin section No. 10 may likely represent a vessel made with different manufacturing processes than the other thin sections in this category. Experimental production of shell temper using burnt mussel shell typically yields easily separable shell platelets which are similar to those noted in the majority of the thin sections. It is possible that a different temper preparation technique may have been used in the case of the shell noted in thin section No. 10. 


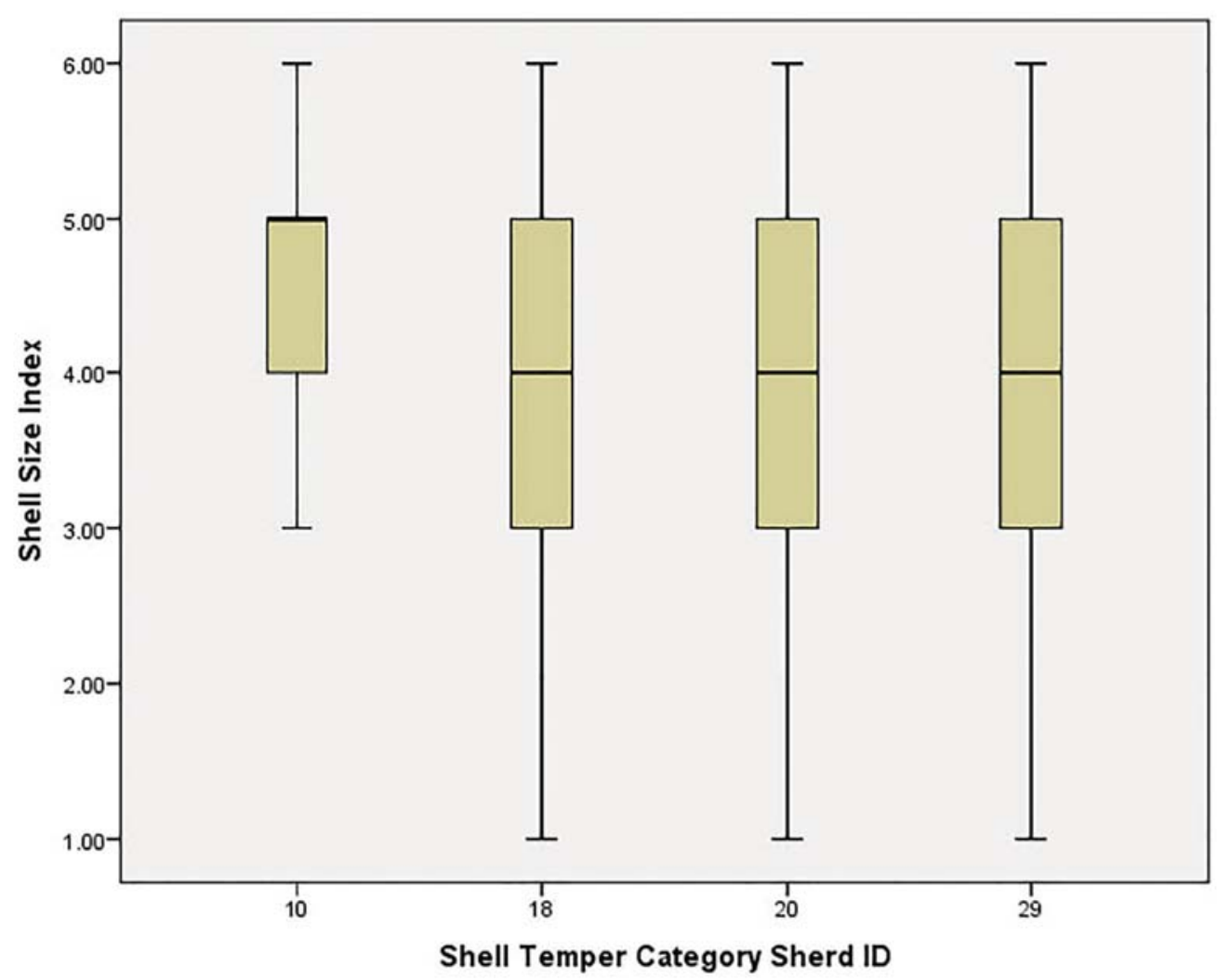

Figure 16. Box plot showing the distribution of shell size for shell-tempered sherds.

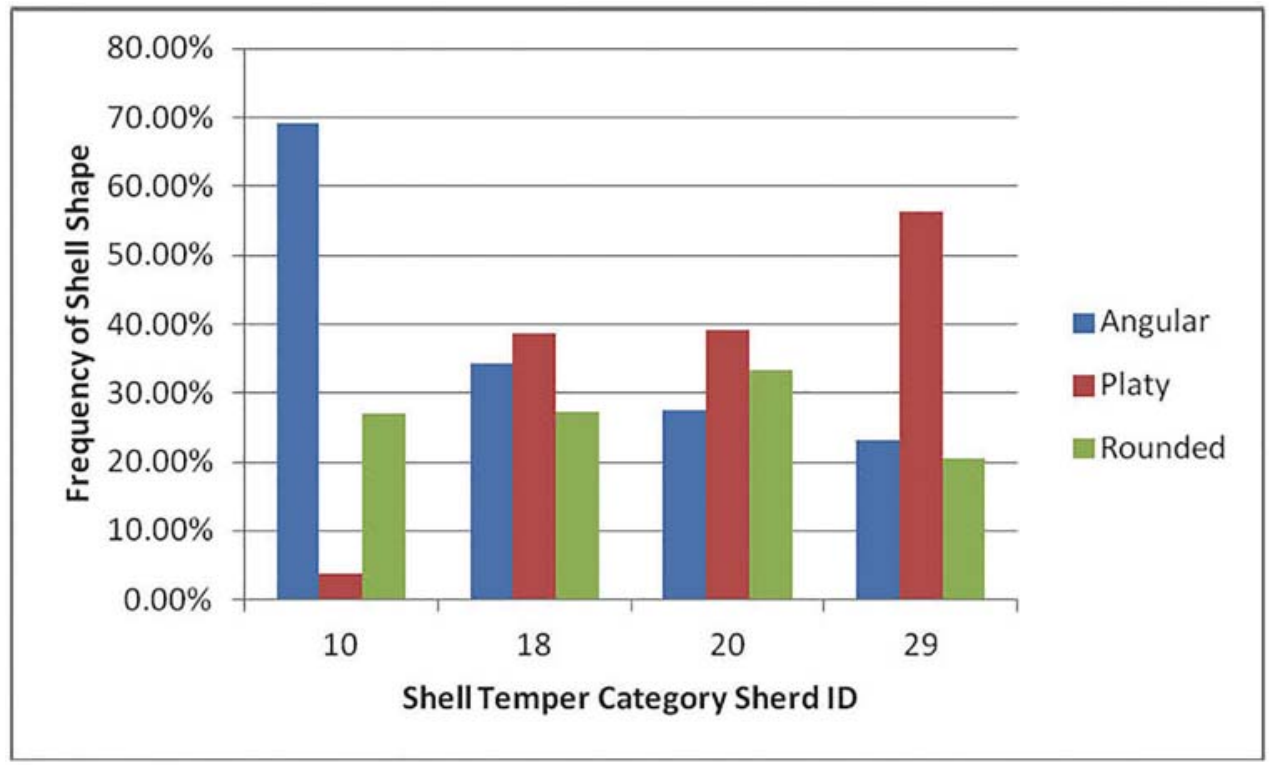

Figure 17. Distribution of shell shape by sherd No.

The percentage of sand in this category ranged from $2.9 \%$ to $4.6 \%$. Figure 18 shows the sand size distribution based on the Wentworth scale. Thin section No. 29 from Moore \#3 (see below) stands out from the other thin sections in this category in that all the sand is silt size. The other thin sections in this category have more variable sand size particles suggesting that they represent vessels made of a variety of distinct clays or they represent a range of manufacture traditions within these shell-tempered vessels. 


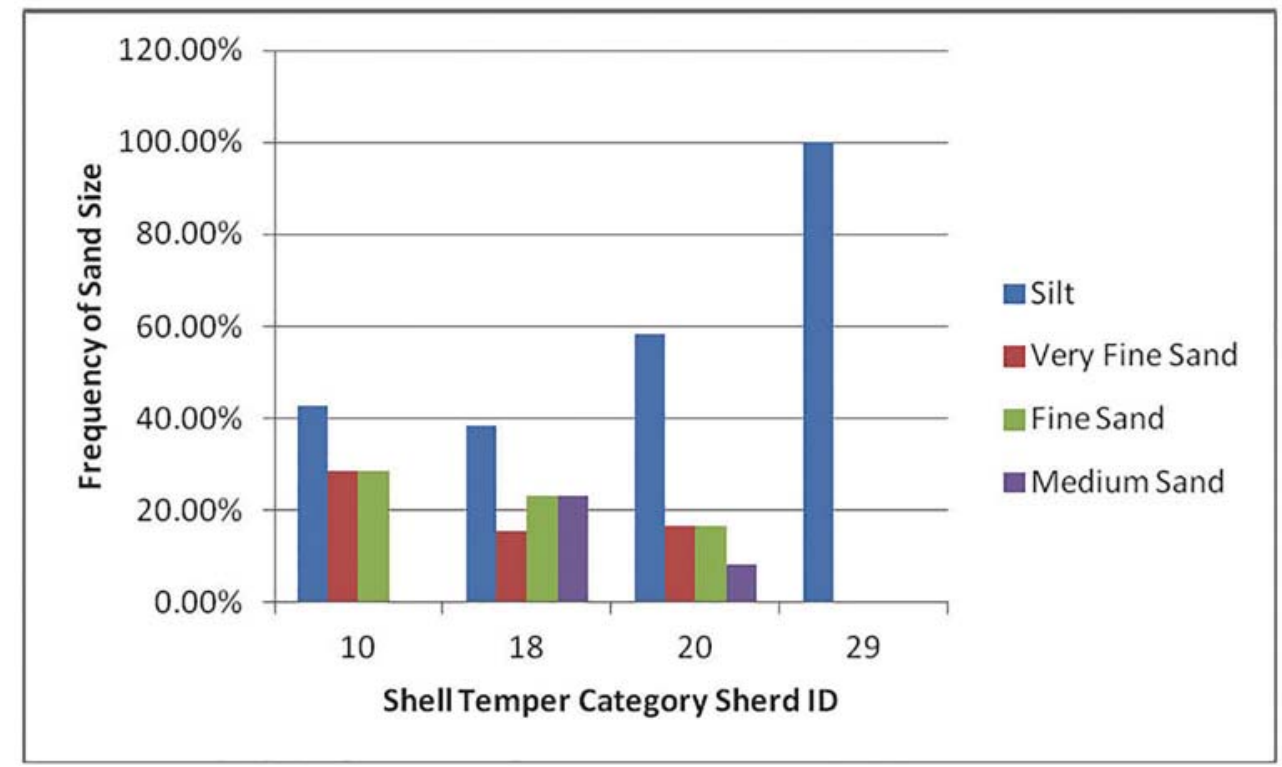

Figure 18. Distribution of the sand size category for shell-tempered sherds based on the Wentworth scale by sherd No.

\section{Sherd No. 10 (Figure 19a)}

Paste Matrix (PPL): Mottled

Paste Color (PPL): 10YR 4/6, dark yellowish-brown with spots of 2.5Y 7/8, yellow

$B$-fabric (XPL): Speckled/Slightly Active

Edge Description: N/A

Comments: Calcium carbonate may also be shell. Most shell is not platy-shaped. No apparent orientation for inclusions.

\section{Point Count}

\begin{tabular}{|l|r|r|l|r|r|}
\hline \multicolumn{1}{|c|}{ Paste/Inclusion } & Count & Percent & $\begin{array}{l}\text { Simplified Inclusion } \\
\text { Category }\end{array}$ & Count & Percent \\
\hline Paste & 200 & $82.0 \%$ & Paste & 200 & $83.7 \%$ \\
\hline Shell & 26 & $10.7 \%$ & Sand & 7 & $2.9 \%$ \\
\hline Quartz & 7 & $2.9 \%$ & Shell & 26 & $10.9 \%$ \\
\hline Calcium carbonate & 5 & $2.0 \%$ & Other & 6 & $2.5 \%$ \\
\hline Hematite & 1 & $0.4 \%$ & Total & 239 & \\
\hline Voids & 5 & $2.0 \%$ & & & \\
\hline Total & $\mathbf{2 4 4}$ & & & & \\
\hline
\end{tabular}

Also present: muscovite (common), alkali feldspar (common), polycrystalline quartz (common)

Percentage of voids that might be missing inclusions: $40 \%$

Inclusion Size (mm)

\begin{tabular}{|l|c|c|c|c|}
\hline & Range & Mean & Median & $\begin{array}{c}\text { Interquartile } \\
\text { Range }\end{array}$ \\
\hline Sand & $.02-.14$ & .08 & .10 & .12 \\
\hline Shell & $.18-1.90$ & .71 & .58 & .51 \\
\hline All Inclusions & $.02-1.90$ & .53 & .44 & .50 \\
\hline
\end{tabular}



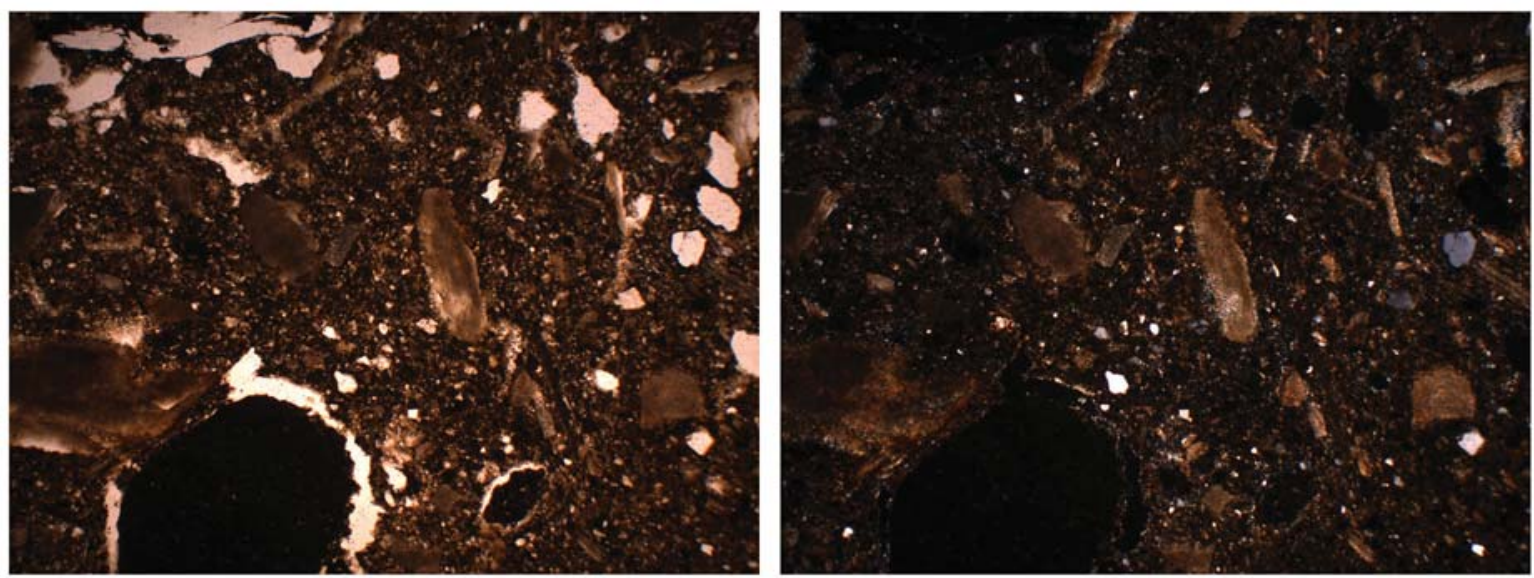

Figure 19a.
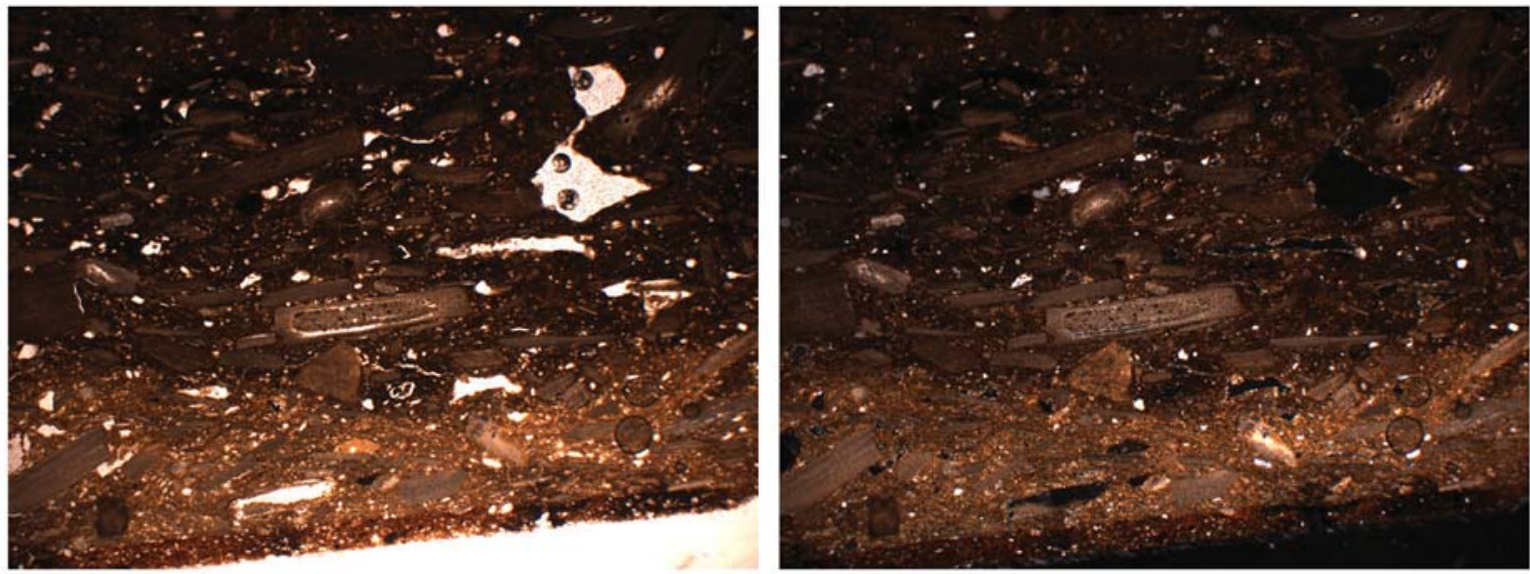

Figure 19b.
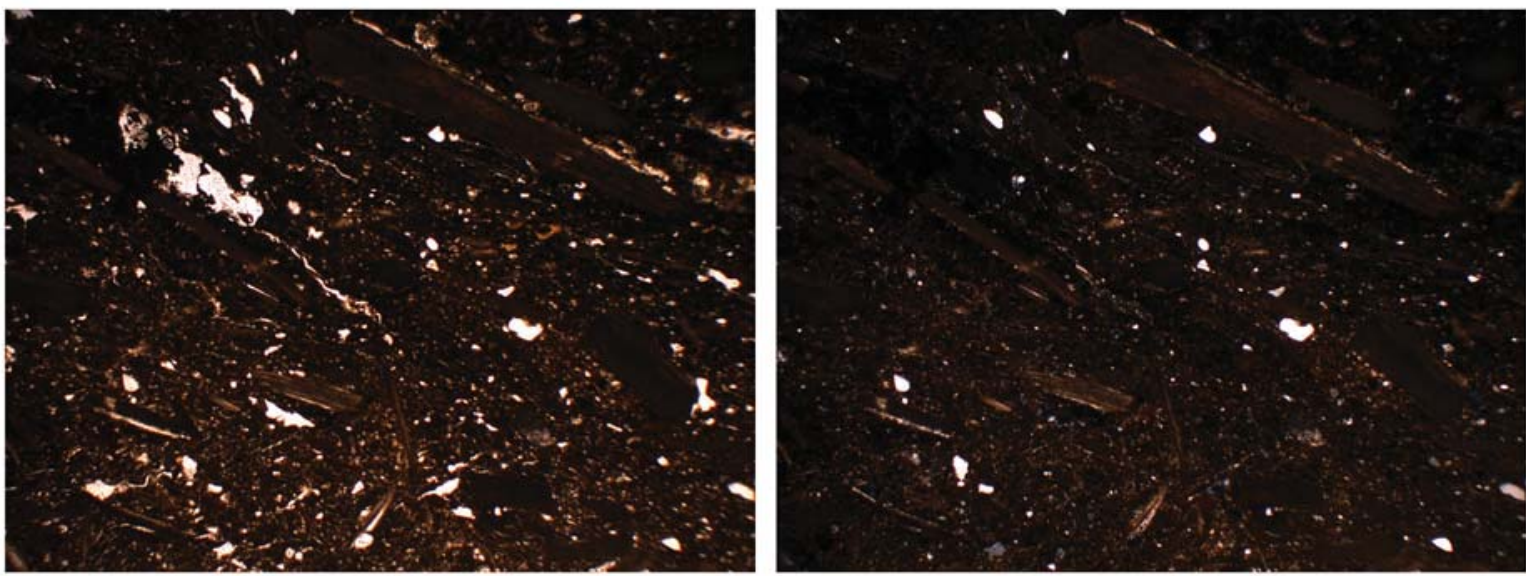

Figure 19c.

Figure 19. Photographs of shell-tempered thin sections: a, No. 10; b, No. 18; c, No. 20. All photographs are at $4 \mathrm{x}$ magnification. The plane light image is on the right and the cross-polar light image is on the left. 


\section{Sherd No. 18 (Figure 19b)}

Paste Matrix (PPL): Zoned

Paste Color (PPL): outside edge: 7.5YR 5/8, strong brown; second layer: 10YR 7/6, yellow; core: 10YR 4/6, dark yellowish-brown

B-fabric (XPL): Outside edge: Specked/Active; second layer: Speckled/Slightly Active; core: mostly Undifferentiated

Edge Description: Possible slip present (shell is not present in outside edge), although spots missing. The edge is mostly missing.

Comments: Most of the shell is platy-shaped and oriented parallel to the rim. The shell in half of the thin section is all dissolved (voids only)

\section{Point Count}

\begin{tabular}{|l|r|r|l|r|l|}
\hline \multicolumn{1}{|c|}{ Paste/Inclusion } & Count & \multicolumn{1}{c|}{ Percent } & $\begin{array}{l}\text { Simplified Inclusion } \\
\text { Category }\end{array}$ & Count & Percent \\
\hline Paste & 200 & $63.4 \%$ & Paste & 200 & $70.7 \%$ \\
\hline Shell & 70 & $22.2 \%$ & Sand & 13 & $4.6 \%$ \\
\hline Quartz & 9 & $2.9 \%$ & Shell & 70 & $24.7 \%$ \\
\hline Polycrystalline quartz & 2 & $0.6 \%$ & Total & $\mathbf{2 8 3}$ & \\
\hline Alkali feldspar & 1 & $0.3 \%$ & & & \\
\hline Microcline & 1 & $0.3 \%$ & & & \\
\hline Voids & 32 & $10.2 \%$ & & & \\
\hline Total & $\mathbf{3 1 5}$ & & & & \\
\hline
\end{tabular}

Also present: plagioclase (common), biotite (rare)

Percentage of voids that might be missing inclusions: 59.4\%

Inclusion Size (mm)

\begin{tabular}{|l|c|c|c|c|}
\hline & Range & Mean & Median & $\begin{array}{c}\text { Interquartile } \\
\text { Range }\end{array}$ \\
\hline Sand & $.02-.36$ & .14 & .10 & .18 \\
\hline Shell & $.04-1.64$ & .44 & .29 & .47 \\
\hline All Inclusions & $.02-1.64$ & .39 & .26 & .42 \\
\hline
\end{tabular}

\section{Sherd No. 20 (Figure 19c)}

Paste Matrix (PPL): Continuous

Paste Color (PPL): 10YR 5/6, yellowish-brown

$B$-fabric (XPL): Speckled/Slightly Active

Edge Description: Same as the rest of the paste

Comments: About half of the shell in the thin section has a cloudy appearance. Shell generally has a platy shape and is oriented parallel to the rim. Organic is likely a plant twig/charcoal.

\section{Point Count}

\begin{tabular}{|l|r|r|l|r|r|}
\hline \multicolumn{1}{|c|}{ Paste/Inclusion } & Count & Percent & $\begin{array}{l}\text { Simplified Inclusion } \\
\text { Categorv }\end{array}$ & Count & Percent \\
\hline Paste & 200 & $73.8 \%$ & Paste & 200 & $75.8 \%$ \\
\hline Shell & 51 & $18.8 \%$ & Sand & 12 & $4.6 \%$ \\
\hline Quartz & 12 & $4.4 \%$ & Shell & 51 & $19.3 \%$ \\
\hline Organic & 1 & $0.4 \%$ & Other & 1 & $0.4 \%$ \\
\hline Voids & 7 & $2.6 \%$ & Total & $\mathbf{2 6 4}$ & \\
\hline Total & $\mathbf{2 7 1}$ & & & & \\
\hline
\end{tabular}

Also present: muscovite (common), plagioclase (uncommon), alkali feldspar (uncommon), microcline (rare)

Percentage of voids that might be missing inclusions: $14.3 \%$ 
Inclusion Size (mm)

\begin{tabular}{|l|c|c|c|c|}
\hline & Range & Mean & Median & $\begin{array}{c}\text { Interquartile } \\
\text { Range }\end{array}$ \\
\hline Sand & $.02-.32$ & .10 & .05 & .11 \\
\hline Shell & $.06-2.0$ & .46 & .36 & .48 \\
\hline All Inclusions & $.02-2.0$ & .39 & .28 & .41 \\
\hline
\end{tabular}

\section{Shell and Grog Temper}

This temper category was distinguished from the shell temper category by the presence of grog in addition to the shell. Only one thin section (No. 22) from the Spiro site was represented in this category. Thin section No. 22 had 3.7\% sand, 10\% grog, and 3.3\% shell. The majority of the sand (89\%) was silt size. Platy shell was common (36\%). The crushed sherds used as temper, were themselves tempered with shell/bone.

\section{Sherd No. 22 (Figure 20)}

Paste Matrix (PPL): Mottled

Paste Color (PPL): 2.5Y 5/6, light olive brown with streaks of 2.5Y 3/3, dark olive brown

B-fabric (XPL): Speckled/Slightly Active

Edge Description: One edge is lighter (2.5Y 7/6, yellow) and more active

Grog Description: Generally tempered with shell and some possibly bone. Some of the inclusions are platy in the crushed sherds.

Comments: Shell is generally platy-shaped and oriented parallel to the rim

\section{Point Count}

\begin{tabular}{|l|r|r|l|r|r|}
\hline \multicolumn{1}{|c|}{ Paste/Inclusion } & Count & \multicolumn{1}{c|}{ Percent } & $\begin{array}{c}\text { Simplified Inclusion } \\
\text { Category }\end{array}$ & Count & Percent \\
\hline Paste & 200 & $79.1 \%$ & Paste & 200 & $83.0 \%$ \\
\hline Grog & 24 & $9.5 \%$ & Sand & 9 & $3.7 \%$ \\
\hline Shell & 8 & $3.2 \%$ & Shell & 8 & $3.3 \%$ \\
\hline Quartz & 8 & $3.2 \%$ & Grog & 24 & $10.0 \%$ \\
\hline Polycrystalline quartz & 1 & $0.4 \%$ & Total & & \\
\hline Voids & 12 & $4.7 \%$ & & & \\
\hline Total & $\mathbf{2 5 3}$ & & & & \\
\hline
\end{tabular}

Also present: hematite (common), bone (uncommon), muscovite (uncommon), plagioclase (rare)

Percentage of voids that might be missing inclusions: $8.3 \%$

\section{Inclusion Size (mm)}

\begin{tabular}{|l|c|c|c|c|}
\hline & Range & Mean & Median & $\begin{array}{c}\text { Interquartile } \\
\text { Range }\end{array}$ \\
\hline Sand & $.02-1.46$ & .19 & .04 & .02 \\
\hline Shell & $.14-.84$ & .32 & .27 & .22 \\
\hline Grog & $.22-1.40$ & .71 & .64 & .66 \\
\hline All Inclusions & $.02-1.46$ & .52 & .38 & .69 \\
\hline
\end{tabular}



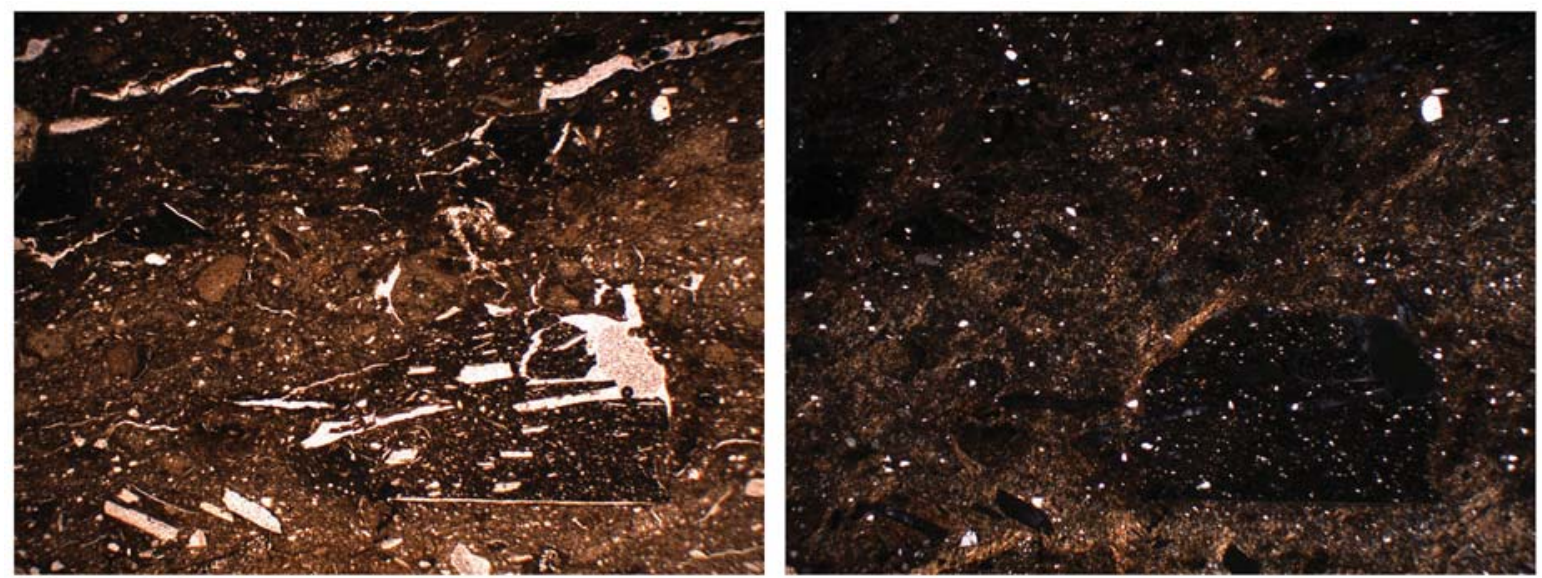

Figure 20.

Figure 20. Photographs of shell-grog tempered thin section No. 22. All photographs are at 4x magnification. The plane light image is on the right and the cross-polar light image is on the left.

\section{Shell, Bone, and Grog Temper}

This temper category was distinguished by the presence of shell, bone, and grog in the thin section. Only one thin section from the Spiro site (No. 16) was represented in this group. Thin section No. 16 had $11.2 \%$ sand, $2.5 \%$ bone, $5.8 \%$ grog, and $6.9 \%$ shell. The sand particles were commonly (48\%) silt sized. The bone inclusions were angular, but the shell inclusions were generally platy in shape (Figure 21). The difference is consistent with the likelihood that bone and shell underwent different processing techniques to transform them into temper. The crushed sherds were generally tempered with sand, shell, shell and bone, or bone.

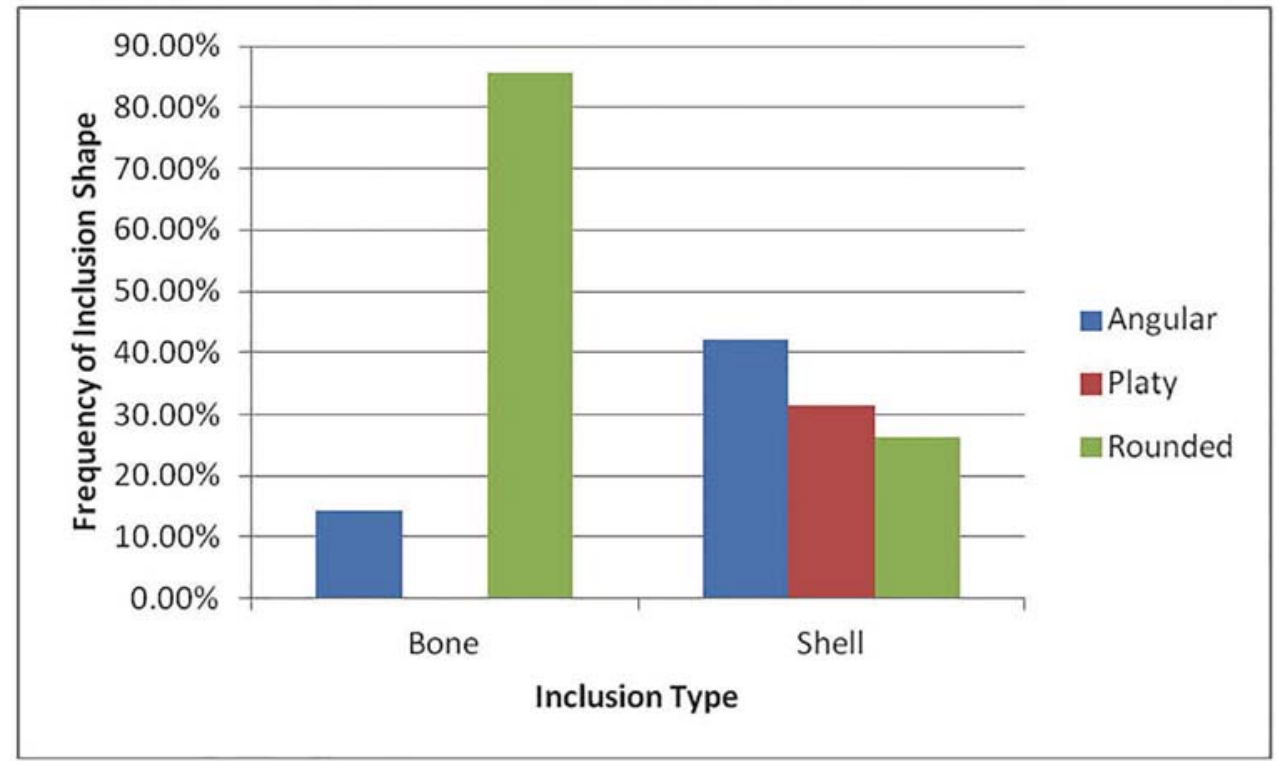

Figure 21. Distribution of bone and shell inclusion shapes for thin section No. 16 from the Spiro site. 


\section{Sherd No. 16 (Figure 22)}

Paste Matrix (PPL): Continuous

Paste Color (PPL): 2.5Y 5/6, light olive brown

B-fabric (XPL): Speckled/Slightly Active

Edge Description: Both edges are rubbed too thin

Grog Description: Generally tempered with sand, shell, shell and bone, or bone. Shell is generally platy-shaped. Comments: Calcite maybe shell or completely replaced bone. Some of the shell temper has a platy shape but not the bone.

\section{Point Count}

\begin{tabular}{|l|r|r|l|r|r|}
\hline \multicolumn{1}{|c|}{ Paste/Inclusion } & Count & Percent & $\begin{array}{c}\text { Simplified Inclusion } \\
\text { Category }\end{array}$ & Count & Percent \\
\hline Paste & 200 & $68.7 \%$ & Paste & 200 & $72.5 \%$ \\
\hline Bone & 7 & $2.4 \%$ & Sand & 31 & $11.2 \%$ \\
\hline Grog & 16 & $5.5 \%$ & Bone & 7 & $2.5 \%$ \\
\hline Shell & 19 & $6.5 \%$ & Shell & 19 & $6.9 \%$ \\
\hline Quartz & 26 & $8.9 \%$ & Grog & 16 & $5.8 \%$ \\
\hline Polycrystalline quartz & 3 & $1.0 \%$ & Other & 3 & $1.1 \%$ \\
\hline Alkali feldspar & 1 & $0.3 \%$ & Total & $\mathbf{2 7 6}$ & \\
\hline Calcite & 3 & $1.0 \%$ & & & \\
\hline Microcline & 1 & $0.3 \%$ & & & \\
\hline Voids & 15 & $5.2 \%$ & & & \\
\hline Total & $\mathbf{2 9 1}$ & & & & \\
\hline
\end{tabular}

Also present: muscovite (common), plagioclase (common), charcoal (rare), hornblende (rare)

Percentage of voids that might be missing inclusions: $21.4 \%$

Inclusion Size (mm)

\begin{tabular}{|l|c|c|c|c|}
\hline & Range & Mean & Median & $\begin{array}{c}\text { Interquartile } \\
\text { Range }\end{array}$ \\
\hline Sand & $.02-.20$ & .08 & .08 & .08 \\
\hline Bone & $.06-.36$ & .19 & .12 & .24 \\
\hline Shell & $.06-1.22$ & .37 & .28 & .42 \\
\hline Grog & $.18-1.22$ & .51 & .40 & .48 \\
\hline All Inclusions & $.02-1.22$ & .26 & .16 & .28 \\
\hline
\end{tabular}
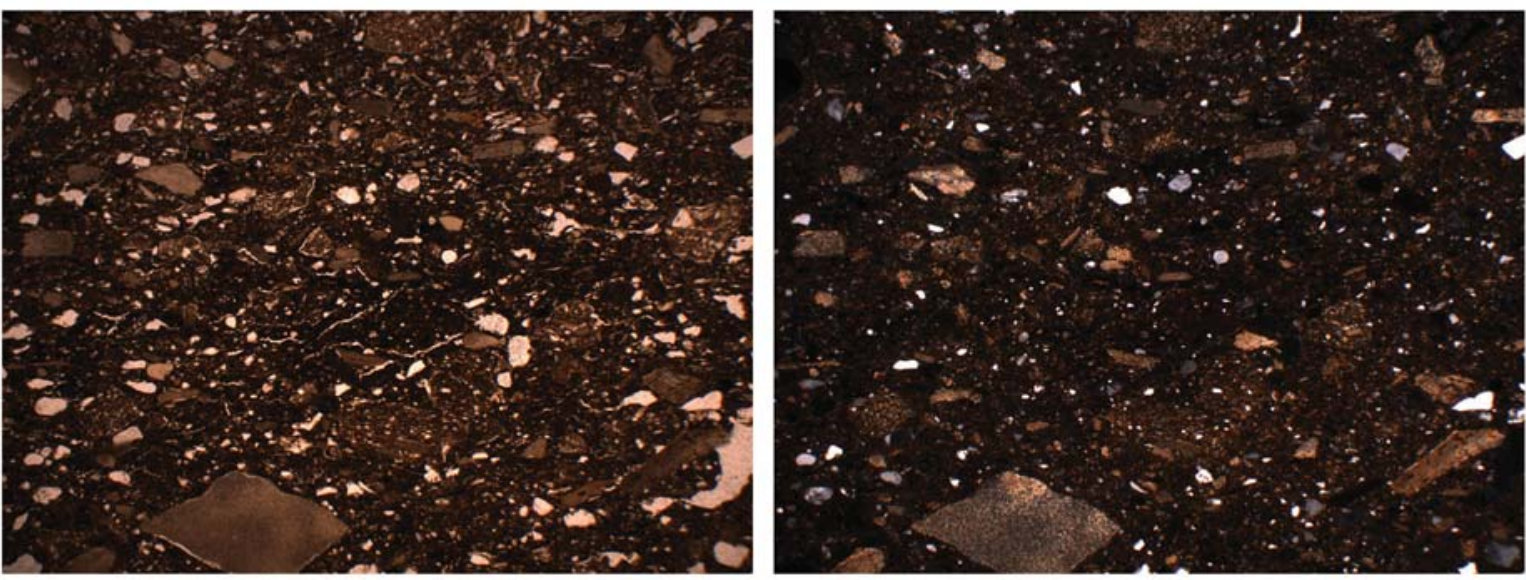

Figure 22.

Figure 22. Photographs of shell-bone-grog tempered thin section No. 16. All photographs are at 4x magnification. The plane light image is on the right and the cross-polar light image is on the left. 


\section{Sherd from the Moore \#3/Ainsworth site}

The one sherd (thin section No. 29) from the Moore \#3 site is shell-tempered. Other paste details include (Figure 23):

Paste Matrix (PPL): Continuous

Paste Color (PPL): 7.5YR 4/6, strong brown

$B$-fabric: Undifferentiated

Edge Description: Edges are slightly lighter in PPL (7.5YR 5/6, strong brown) and slightly active in XPL Comments: Most of the shell is platy-shaped and oriented parallel to the rim.

\section{Point Count}

\begin{tabular}{|l|r|r|l|r|r|}
\hline \multicolumn{1}{|c|}{ Paste/Inclusion } & Count & Percent & $\begin{array}{c}\text { Simplified Inclusion } \\
\text { Category }\end{array}$ & Count & Percent \\
\hline Paste & 200 & $57.8 \%$ & Paste & 200 & $61.2 \%$ \\
\hline Shell & 117 & $33.8 \%$ & Sand & 10 & $3.1 \%$ \\
\hline Quartz & 10 & $2.9 \%$ & Shell & 117 & $35.8 \%$ \\
\hline Voids & 19 & $5.5 \%$ & Total & $\mathbf{3 2 7}$ & \\
\hline Total & $\mathbf{3 4 6}$ & & & & \\
\hline
\end{tabular}

Also present: muscovite (common), alkali feldspar (rare)

Percentage of voids that might be missing inclusions: $0 \%$

Inclusion Size (mm)

\begin{tabular}{|l|c|c|c|c|}
\hline & Range & Mean & Median & $\begin{array}{c}\text { Interquartile } \\
\text { Range }\end{array}$ \\
\hline Sand & $.02-.06$ & .04 & .04 & .04 \\
\hline Shell & $.06-1.96$ & .55 & .42 & .59 \\
\hline All Inclusions & $.02-1.96$ & .51 & .40 & .60 \\
\hline
\end{tabular}
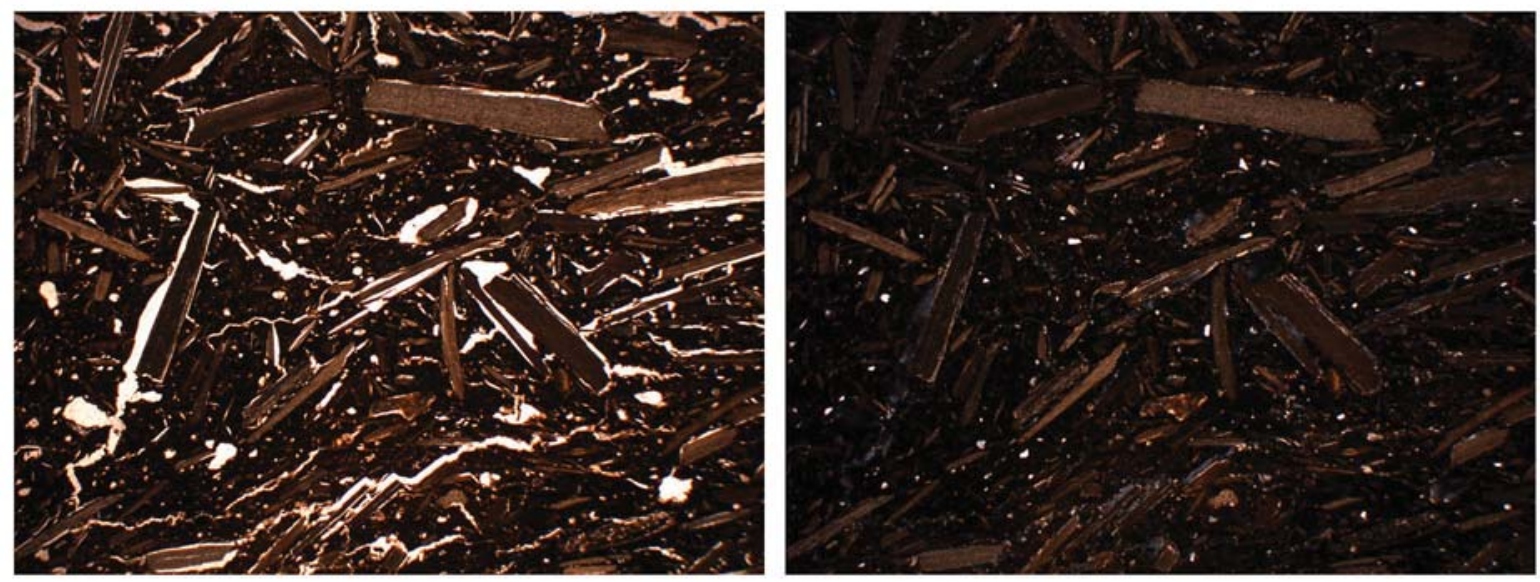

Figure 23.

Figure 23. Photographs of shell-tempered thin section No. 29 from the Moore \#3 site. All photographs are at $4 \mathrm{x}$ magnification. The plane light image is on the right and the cross-polar light image is on the left. 


\section{Sherd from the Geren site}

The sherd/thin-section from the Geren site is the most distinctive in the analyzed sample because of the presence in the paste of biotite and mica schist as temper. Thin section No. 28 from Geren had $13.2 \%$ sand and $14.6 \%$ mica. Given the variability in the sand size (Figures 24 and 25), it is possible that sand was added as temper to a very micaceous clay:

Paste Matrix (PPL): Half \& Half (possibly due to one side of the thin section is ground too thin) Paste Color (PPL): 10YR 5/6, yellowish-brown and 10YR 7/6, yellow $B$-fabric (XPL): Striated/Active

Edge description: Edges same as the rest of the paste.

Grog description: N/A

Comments: In PPL most of the paste is pleochroic due to the amount of biotite. Unknown might be burnt shell or clay pellet

\section{Point Count}

\begin{tabular}{|l|r|r|l|r|r|}
\hline \multicolumn{1}{|c|}{ Paste/Inclusion } & Count & \multicolumn{1}{c|}{ Percent } & $\begin{array}{c}\text { Simplified Inclusion } \\
\text { Category }\end{array}$ & Count & Percent \\
\hline Paste & 200 & $66.7 \%$ & Paste & 200 & $71.4 \%$ \\
\hline Quartz & 13 & $4.3 \%$ & Sand & 37 & $13.2 \%$ \\
\hline Polycrystalline quartz & 20 & $6.7 \%$ & Mica & 41 & $14.6 \%$ \\
\hline Alkali feldspar & 4 & $1.3 \%$ & Other & 2 & $0.7 \%$ \\
\hline Muscovite & 1 & $0.3 \%$ & Total & $\mathbf{2 8 0}$ & \\
\hline Hematite & 1 & $0.3 \%$ & & & \\
\hline Biotite & 20 & $6.7 \%$ & & & \\
\hline Mica Schist & 20 & $6.7 \%$ & & & \\
\hline Unknown & 1 & $0.3 \%$ & & & \\
\hline Voids & 20 & $6.7 \%$ & & & \\
\hline Total & $\mathbf{3 0 0}$ & & & & \\
\hline
\end{tabular}

Also present: plagioclase (rare)

Percentage of voids that might be missing inclusions: $0 \%$

Inclusion Size (mm)

\begin{tabular}{|l|c|c|c|c|}
\hline & Range & Mean & Median & $\begin{array}{c}\text { Interquartile } \\
\text { Range }\end{array}$ \\
\hline Sand & $.04-1.22$ & .31 & .22 & .37 \\
\hline Mica & $.02-1.34$ & .31 & .20 & .32 \\
\hline All Inclusions & $.02-1.34$ & .32 & .21 & .34 \\
\hline
\end{tabular}




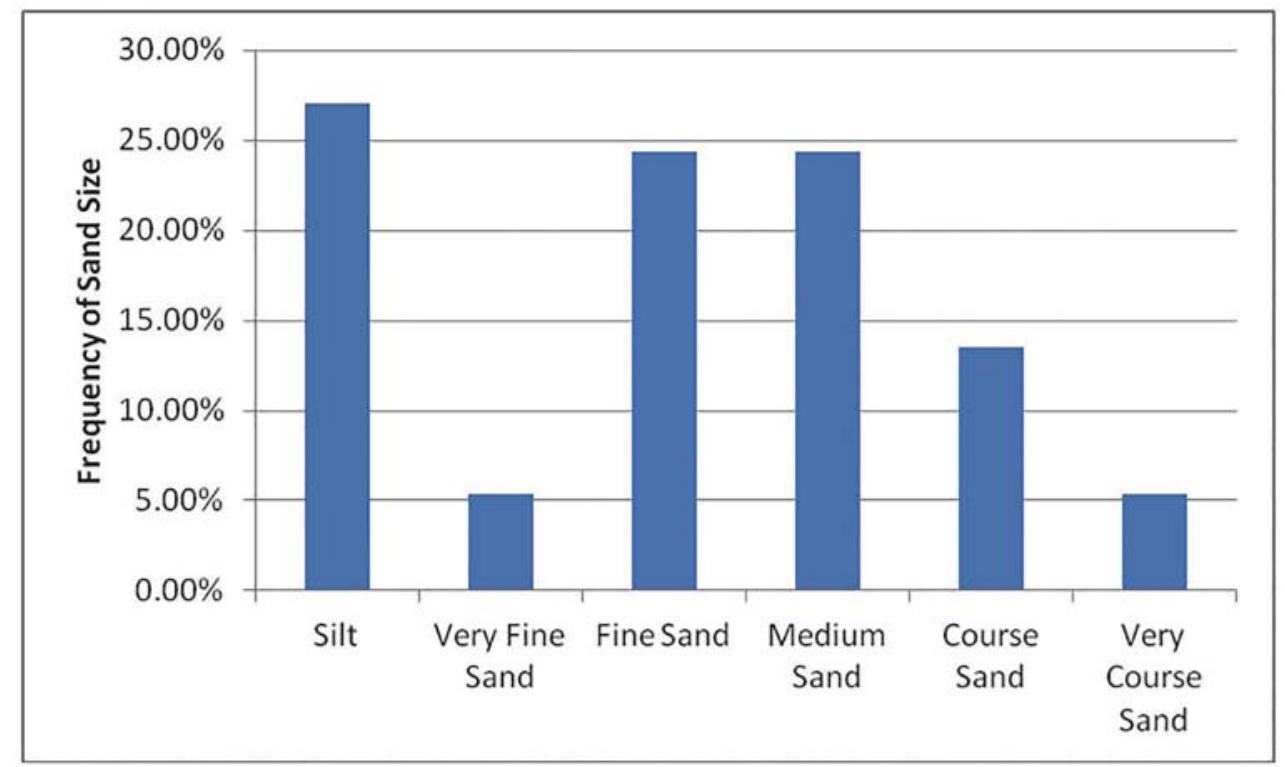

Figure 24. Size distribution for sand in thin section No. 28 from the Geren site.
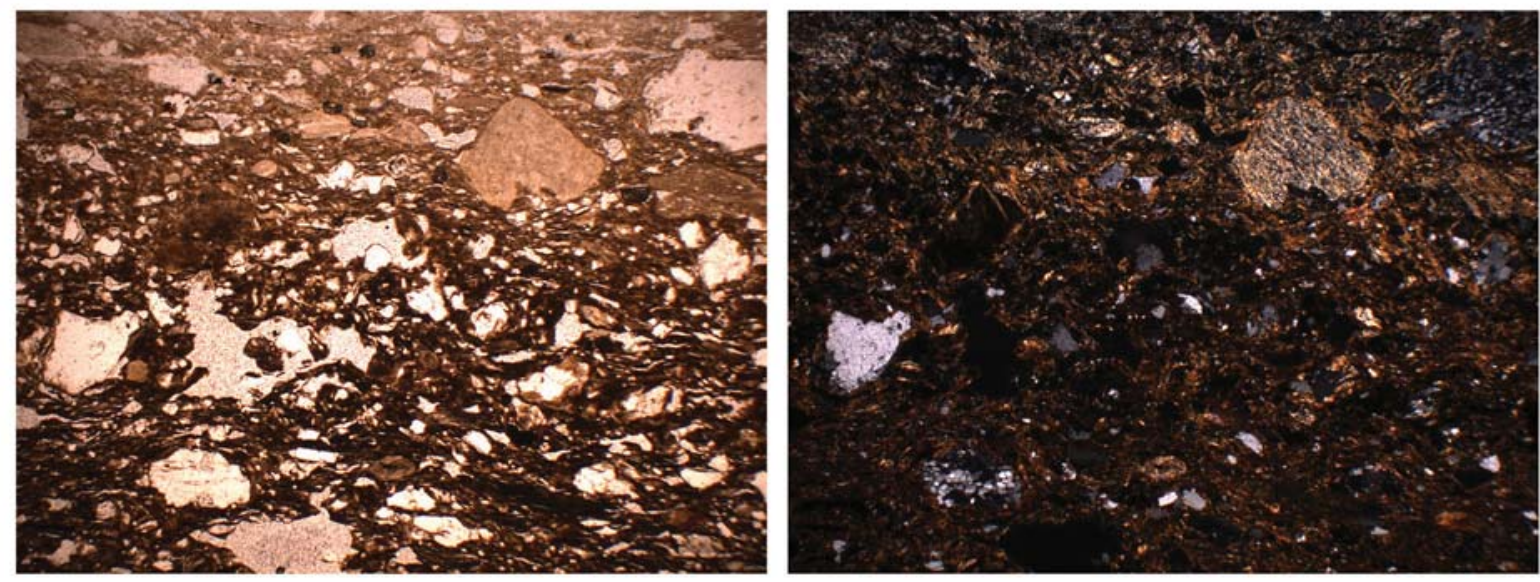

Figure 25.

Figure 25. Photographs of micaceous-tempered thin section No. 29 from the Geren site. All photographs are at $4 \mathrm{x}$ magnification. The plane light image is on the right and the cross-polar light image is on the left. 


\section{Summary and Conclusions}

The petrographic analysis of the 23 thin sections of ceramic vessel sherds from the Spiro, Moore \#3, and Geren sites in the Arkansas River basin in eastern Oklahoma has identified eight temper categories based on the percentage of inclusions recorded during point counting. It is unclear whether the temper variation is due to differences in production locale, temporal variation, or ware type (fine ware vs. utility ware), but more than likely the variation is due to all three factors. It has been established that shell-tempered ceramics in the Arkansas River basin in eastern Oklahoma generally replace grog and/or-bone-tempered ceramics after ca. A.D. 1250, although Brown (1996:157) notes the "coexistence of locally made shell tempered pottery and grog and grog-grit-bone pottery" at the Harlan site, another important mound center in the Arkansas River basin, during the Harlan phase (ca. A.D. 1050-1250). Furthermore, he notes that grogs "composed of crushed shell tempered pottery is...very distinctive of the Harlan phase at Spiro."

With the exception of the micaceous sand temper category, the other temper categories consist of some variation of bone, shell, and/or grog. The sherds from the Spiro site with grog, bone-grog, and bone temper are from Williams Plain, Sanders Plain, Spiro Engraved, Redland Engraved, Agee Incised, and LeFlore Plain vessels (see Tables 2 and 4). The few from established contexts date from ca. A.D. 1000-1450.

Two shell-grog and shell-bone-grog sherds (thin sections No. 16 and No. 22) were classified as Sanders Plain, a grog-tempered slipped type, by Brown (1996) (see Table 2); the temper apparent in the grog is bone/shell. Brown (1996:401) does note that Sanders Plain vessels do have "grog temper in which finely divided shell is included in the grog."

Two of the sherds (No. 19 and 26) had been classified as Poteau Plain, a slipped shell-tempered ware (Brown 1996:405), by Brown (see Table 2), but they have bone temper (see Table 4). These sherds, both of which are red-slipped, are better included in the Sanders Plain group in this assemblage. Another sherd identified through petrographic analysis as having bone temper-thin section No. 14-was classified by Brown as Bell Plain (see Table 2); this sherd was found in a Norman phase context (see Table 1). Since Bell Plain is an undecorated fine-shell ware (Brown 1996:392), sherd thin section No. 14 should be reclassified as coming from a plain bone-tempered vessel of uncertain type.

The shell-tempered sherds represented in the analyzed thin sections include Woodward Plain, from the Moore \#3 site, and three sherds of red-slipped Poteau Plain (No. 10, No. 18, and No. 20) (see Table 2). They are from post-A.D. 1250 contexts at the Spiro and Moore \#3 sites.

The micaceous sand-tempered neck banded sherd from the Geren site definitely stands out from all the other thin sections and may represent a fragment from an exotic or non-local ceramic vessel. However, it should also be noted that thin section No. 23 (grog-tempered), from a LeFlore Plain vessel, had a small mica schist fragment and biotite was also recorded. It is possible, therefore, that these mica fragments came from the addition of crushed micaceous sand-tempered sherds; this suggests that the micaceous sand-tempered pottery may possibly have been made in a locale not that far removed from the Spiro mound area, although that seems unlikely. Instead, we consider this sherd to have come from a non-shell-tempered Nash Neck Banded vessel made by a Caddo potter in the Red River basin after ca. A.D. 1300, among either a McCurtain phase Caddo group living in the Glover River or Mountain Fork drainages in southeastern Oklahoma (see Dowd 2012; Regnier 2013:48-51) or a Texarkana phase Caddo group on the Red River itself (see Perttula and Nelson 2003). 
While we do believe that a discussion of the human behavior implicated by these petrographic differences and similarities among the sherds from the Spiro site and other eastern Oklahoma Arkansas River basin sites is what we all strive to accomplish and get to, the small size of the present sample limits such broad generalizations. For example, while differences in temper processing, such as platy versus unplaty bone inclusion, may relate to social learning or different communities of practice, however, this sample of thin sections is too diverse (temporally and by ceramic types) and lacks sufficient context to be able to discuss how they relate to human behavior. The goal of this petrographic analysis project was to provide a general characterization of the paste and temper to help guide future research on the ceramics from the region. As sample sizes increase and are more solidly provenienced, such broader conclusions would be warranted. The same thing can be said about the behavioral implications of the minor inclusions in the sherd pastes. More samples would be needed to discern the importance of the minor inclusions in considering the character of the pastes and in distinguishing sand sources.

The four most common temper categories (bone, bone and grog, grog, and shell) in the analyzed sherd thin sections were not homogeneous categories and there was considerable paste variation within each category. With a larger sample size of sherd thin sections from other Spiro area ceramic assemblages, it may be possible to further break down these temper categories into more homogeneous groups with regionallyspecific temporal and/or technological characteristics. Of particular interest was the variation in bone and/ or shell temper shape and the type of crushed sherds (i.e., grog) used as temper. Future petrographic research should focus on these variations as they relate to ceramic vessel manufacturing/technological processes, which in turn may provide insights into the existence of different ceramic traditions made by spatially and temporally distinct northern Caddo groups within the region.

\section{Acknowledgments}

We wish to thank Dr. James A. Brown for encouraging this belated study of the petrographic thinsections from the Spiro, Geren, and Moore sites in eastern Oklahoma. Of course, we are particularly grateful that he sent the thin sections for study in the first place, and we are glad that we have finally been able to see the petrographic analysis completed. Thanks also to Dr. Reid Ferring for passing the thin-sections and sherds along to Perttula, and to Dr. Scott W. Hammerstedt, Dr. George Avery, and two anonymous peer reviewers for

providing comments on the manuscript. Dr. Elsbeth Dowd provided Sam Noble Oklahoma Museum of Natural History provenience information for the sherds and thin sections. 


\section{References Cited}

Brown, J. A.

1966 Spiro Studies, Vol. 2. The Graves and Their Contents. University of Oklahoma Research Institute, Norman.

1971 Spiro Studies, Vol. 3, Pottery Vessels. First Part of the Third Annual Report of Caddoan Archaeology-Spiro Focus Research. University of Oklahoma Research Institute, Norman.

1996 The Spiro Ceremonial Center. The Archaeology of Arkansas Valley Caddoan Culture in Eastern Oklahoma. 2 Vols. Memoir No. 29. Museum of Anthropology, University of Michigan, Ann Arbor.

Ferring, C. R. and T. K. Perttula

1987 Defining the Provenance of Red-Slipped Pottery from Texas and Oklahoma by Petrographic Methods. Journal of Archaeological Science 14:437-456.

Galehouse, J. S.

1971 Point Counting. In Procedures in Sedimentary Petrology, edited by R. E. Carver, pp. 385-407. Wiley-Interscience, New York.

Perttula, T. K. and B. Nelson

2003 Archeological Investigations of Village Areas at the Hatchel Site (41BW3), Bowie County, Texas. Report of Investigations No. 58. Archeological \& Environmental Consultants, LLC, Austin.

Peterson, D. A, J. D. Rogers, D. G. Wyckoff, and K. Dohm

1993 An Archeological Survey of the Spiro Vicinity, LeFlore County, Oklahoma. Archeological Resources Survey Report No. 37. Oklahoma Archeological Survey, Norman.

Porter, J. W.

1971 Thin-Section Identifications of Spiro Sherds. In Spiro Studies, Volume 3: Pottery Vessels, by J. A. Brown, pp. 244-246. First Part of the Third Annual Report of Caddoan Archaeology-Spiro Focus Research. Stovall Museum of Science and History, University of Oklahoma and The University of Oklahoma Research Institute, Norman.

Quinn, P. S.

2013 Ceramic Petrography: The Interpretation of Archaeological Pottery and Related Artefacts in Thin Section. Archaeopress, Oxford.

Rogers, J. D.

2006 Chronology and the Demise of Chiefdoms: Eastern Oklahoma in the Sixteenth and Seventeenth Centuries. Southeastern Archaeology 25(1):20-28.

Rohrbaugh, C. L.

1985 LfGeI, the Geren Site, 34Lf36, of the Spiro Phase. Bulletin of the Oklahoma Anthropological Society 34:9-81.

2012 Spiro and Fort Coffee Phases: Changing Cultural Complexes of the Caddoan Area. Memoir 16. Oklahoma Anthropological Society, Norman. 


\section{References Cited (cont.)}

Stoltman, J. B.

1989 A Quantitative Approach to the Petrographic Analysis of Ceramic Thin Sections. American Antiquity 54(1):147-160.

2012 Appendix H: Ceramic Thin Section Analyses. In Early Ceramic Occupation along Blackbird Creek: Archaeological Investigations at Blackbird Creek Site (7NC-J-195D) New Castle County, Delaware, edited by C. Bowen, pp. H1-H13. Cultural Resources Division, Versar, Inc., Springfield, Virginia.

Stoops, G.

2003 Guidelines for Analysis and Description of Soil and Regolith Thin Sections. Soil Science of America, Inc., Madison.

Suhm, D. A. and E. B. Jelks (editors)

1962 Handbook of Texas Archeology: Type Descriptions. Special Publication No. 1, Texas Archeological Society, and Bulletin No. 4, Texas Memorial Museum, Austin. 